\title{
Stimulation of microbial nitrogen cycling in aquatic ecosystems by benthic macrofauna: mechanisms and environmental implications
}

\author{
P. Stief ${ }^{1,2}$ \\ ${ }^{1}$ Max Planck Institute for Marine Microbiology, Microsensor Group, Bremen, Germany \\ ${ }^{2}$ University of Southern Denmark, Department of Biology, NordCEE, Odense, Denmark \\ Correspondence to: P. Stief (peterstief@biology.sdu.dk) \\ Received: 1 July 2013 - Published in Biogeosciences Discuss.: 15 July 2013 \\ Revised: 27 October 2013 - Accepted: 30 October 2013 - Published: 2 December 2013
}

\begin{abstract}
Invertebrate animals that live at the bottom of aquatic ecosystems (i.e., benthic macrofauna) are important mediators between nutrients in the water column and microbes in the benthos. The presence of benthic macrofauna stimulates microbial nutrient dynamics through different types of animal-microbe interactions, which potentially affect the trophic status of aquatic ecosystems. This review contrasts three types of animal-microbe interactions in the benthos of aquatic ecosystems: (i) ecosystem engineering, (ii) grazing, and (iii) symbiosis. Their specific contributions to the turnover of fixed nitrogen (mainly nitrate and ammonium) and the emission of the greenhouse gas nitrous oxide are evaluated.

Published data indicate that ecosystem engineering by sediment-burrowing macrofauna stimulates benthic nitrification and denitrification, which together allows fixed nitrogen removal. However, the release of ammonium from sediments is enhanced more strongly than the sedimentary uptake of nitrate. Ecosystem engineering by reef-building macrofauna increases nitrogen retention and ammonium concentrations in shallow aquatic ecosystems, but allows organic nitrogen removal through harvesting. Grazing by macrofauna on benthic microbes apparently has small or neutral effects on nitrogen cycling. Animal-microbe symbioses provide abundant and distinct benthic compartments for a multitude of nitrogen-cycle pathways. Recent studies reveal that ecosystem engineering, grazing, and symbioses of benthic macrofauna significantly enhance nitrous oxide emission from shallow aquatic ecosystems.

The beneficial effect of benthic macrofauna on fixed nitrogen removal through coupled nitrification-denitrification can thus be offset by the concurrent release of (i) ammonium that
\end{abstract}

stimulates aquatic primary production and (ii) nitrous oxide that contributes to global warming. Overall, benthic macrofauna intensifies the coupling between benthos, pelagial, and atmosphere through enhanced turnover and transport of nitrogen.

\section{Introduction}

Sediments of lakes, streams, and marine coasts are major compartments of the microbial nitrogen cycling in aquatic ecosystems (Thamdrup and Dalsgaard, 2008). Much of the particulate organic nitrogen (PON) that settles onto sediments is rapidly converted to ammonium (Fig. 1). At the oxic sediment surface, ammonium is oxidized to nitrite and further to nitrate by two functional groups of nitrifying Bacteria: ammonia oxidizers and nitrite oxidizers. Additionally, ammonia oxidation is mediated by Archaea that occur ubiquitously in aquatic sediments. Nitrite and nitrate produced by nitrifiers may diffuse partially into the water column and partially into anoxic sediment layers where these nitrogen compounds are reduced through three different nitrogencycle pathways to either dinitrogen (i.e., by denitrification and anaerobic ammonium oxidation, anammox) or ammonium (i.e., by dissimilatory nitrate reduction to ammonium, DNRA) by facultatively or strictly anaerobic Bacteria and Archaea. In nitrate-rich aquatic ecosystems, nitrate also directly diffuses from the water column into anoxic sediment layers where it is reduced to either dinitrogen or ammonium. Additionally, nitrate and ammonium can be taken up, stored intracellularly, and assimilated by heterotrophic Bacteria, Archaea, and benthic microalgae at the sediment surface 


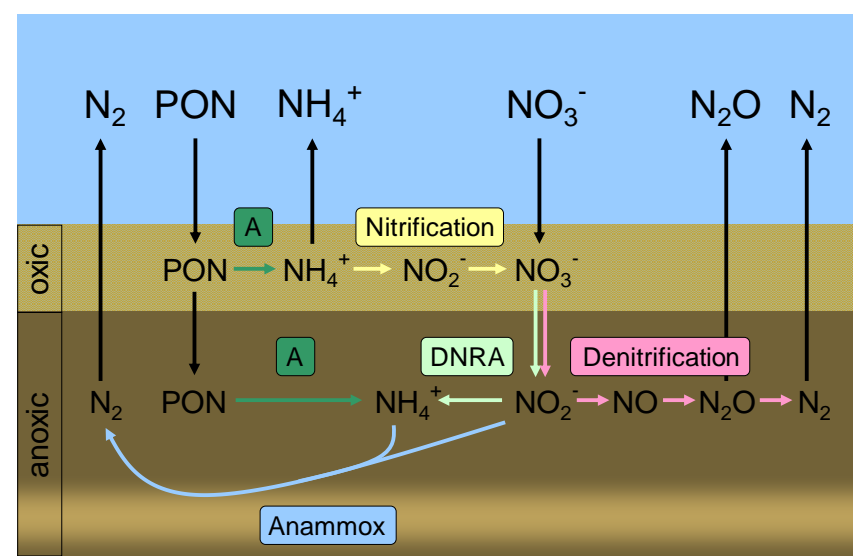

Fig. 1. The benthic microbial nitrogen cycle in aquatic ecosystems with nitrate present in the water column. Black arrows indicate the predominant routes of net transport of particles or solutes between water and sediment. Colored arrows indicate conversions along individual nitrogen-cycle pathways. PON: particulate organic nitrogen, A: ammonification, DNRA: dissimilatory nitrate reduction to ammonium, Anammox: anaerobic ammonium oxidation. Boxed labels on the left demarcate oxic and anoxic layers within the sediment. To simplify matters, the pathway nitrogen fixation $\left(\mathrm{N}_{2} \rightarrow \mathrm{NH}_{4}^{+}\right)$is omitted.

(Veuger et al., 2007). This cellular pool of fixed nitrogen will partially become available again to the benthic community upon cell lysis. In summary, benthic mineralization of PON and the ensuing microbial nitrogen conversions produce dissolved inorganic nitrogen (DIN) that partially diffuses back into the water column where it fuels primary production. The PON and DIN pools remaining inside the sediment are permanently buried (as PON) or converted to dinitrogen (from DIN) and are thus biologically unavailable to most organisms in the ecosystem. Thus, permanent burial of PON, denitrification, and anammox directly contribute to fixed nitrogen removal from aquatic ecosystems, while ammonification, nitrification, and DNRA only recycle fixed nitrogen. When coupled to denitrification and anammox, however, also the latter three processes contribute to fixed nitrogen removal (e.g., by coupled nitrification-denitrification; Jenkins and Kemp, 1984).

Current concerns arise from excess fixed nitrogen in the environment due to (i) extensive use of synthetic fertilizers in agriculture with subsequent leaching of nitrate into water bodies and (ii) fossil fuel burning followed by atmospheric nitrogen deposition (Gruber and Galloway, 2008; Feuchtmayr et al., 2009). Excess nitrate and ammonium in aquatic ecosystems contribute to eutrophication with detrimental consequences for the environment, such as algal blooms, oxygen depletion, habitat degradation, and loss of biodiversity (Nixon, 1995; Rabalais, 2002; Feuchtmayr et al., 2009; Howarth et al., 2011). The microbial nitrogen cycle (Ncycle) also produces compounds that are toxic to fish (e.g., nitrite, ammonia) and a potent greenhouse gas (i.e., nitrous oxide) at rates often directly proportional to DIN concentrations in the water column (Seitzinger and Kroeze, 1998). Environmental problems arising from excess fixed nitrogen pertain to both freshwater and coastal marine ecosystems and call for management strategies that reduce the sources of fixed nitrogen and/or increase the capacity of fixed nitrogen removal.

Benthic microbes, including Bacteria and Archaea involved in the nitrogen cycle (hereafter: N-cycle microbes), share their habitat with a large diversity of invertebrate animals. In fact, some of the abundant benthic macrofauna species act as important mediators between $\mathrm{N}$-cycle microbes in the benthos and fixed nitrogen in the water column. The burrowing activity by macrofauna entrains fresh organic matter into the sediment (Kamp and Witte, 2005) and extends the oxic-anoxic interface to deeper sediment layers (Laverock et al., 2011). The ventilation activity by macrofauna inside the burrows tremendously enhances the transport of solutes and suspended particles between water column and sediment (Aller and Aller, 1998). By such bioturbation activities (i.e., particle reworking and burrow ventilation; Kristensen et al., 2012), macrofauna may stimulate microbial nitrogen cycling, which is particularly intense at oxic-anoxic interfaces (Thamdrup, 2012), and the transport of DIN and PON between the sediment and the water column (Kristensen and Kostka, 2005). Macrofaunal grazing on Bacteria, Archaea, and microalgae may liberate part of the cellular pools of fixed nitrogen and thereby fuel N-cycle pathways. All of these stimulatory effects by macrofauna potentially remove fixed nitrogen from aquatic ecosystems through the sequential action of ammonification, nitrification, and denitrification and/or anammox (Fig. 1).

In fact, the effects of benthic macrofauna on the aquatic $\mathrm{N}$-cycle are often studied in the context of excess fixed nitrogen in aquatic ecosystems. Many of these studies suggestively link the stimulation of benthic nitrogen cycling by macrofauna to fixed nitrogen removal at the ecosystem level. A factual reduction of DIN concentrations in the water column, the key criterion of ecosystem-level fixed nitrogen removal, will limit primary production and slow down or even reverse the eutrophication process. Fixed nitrogen removal from the aquatic ecosystems occurs through (i) long-term PON burial in deep sediment, (ii) dinitrogen emission to the atmosphere, (iii) feeding on aquatic organisms by birds and terrestrial animals, and (iv) harvesting of aquatic biomass by humans. Hereof, benthic macrofauna potentially affects dinitrogen emission by stimulating microbial $\mathrm{N}$-cycle pathways. However, recent findings reveal that microbial nitrous oxide production can be directly associated with many freshwater and marine macrofauna species and their burrows in the sediment, which potentially increases total nitrous oxide emission rates from aquatic ecosystems (Stief et al., 2009; Heisterkamp et al., 2010). Interestingly, the stimulation of fixed nitrogen removal and nitrous oxide emission by benthic 
macrofauna may occur in parallel and due to the same microbial process (i.e., denitrification; Poulsen et al., 2013).

In the last two decades, some of the mechanisms of macrofauna-induced stimulation of benthic nitrogen cycling and the microbes affected by this stimulation have been unraveled by making use of methodological advancements. Non-invasive microsensors were used in burrows, guts, and exoskeletal biofilms of benthic macrofauna to uncover the microscale oxygen and DIN dynamics in these animalassociated compartments (Stief and de Beer, 2006; Stief and Eller, 2006; Stief et al., 2009; Heisterkamp et al., 2013). Additionally, the molecular, cultivation-independent community analysis of Bacteria and Archaea allowed specifically detecting $\mathrm{N}$-cycle microbes directly in the environment, for instance, by using fluorescence in situ hybridization (FISH) targeting nitrifying Bacteria (Altmann et al., 2004; Stief and de Beer, 2006) or by sequencing of phylogenetic marker genes or functional genes of nitrifying and denitrifying Bacteria and Archaea (Dollhopf et al., 2005; Satoh et al., 2007; Stief et al., 2009; Svenningsen et al., 2012; Gilbertson et al., 2012; Poulsen et al., 2013).

This review article evaluates in which way the presence of benthic macrofauna mitigates or aggravates environmental problems caused by excess fixed nitrogen in aquatic ecosystems. Three different types of animal-microbe interactions (and their transition forms) are discussed with respect to mechanism, representative examples, and ecosystem-level impact on nitrogen cycling: (i) ecosystem engineering, (ii) grazing, and (iii) symbiosis. Particular attention is paid to the recent discovery that significant production of nitrous oxide is directly or indirectly associated with benthic macrofauna.

\section{Interactions between benthic macrofauna and nitrogen-cycle microbes}

\subsection{Ecosystem engineering}

\subsubsection{Sediment infauna}

Many benthic macrofauna species construct sedimentary burrows that serve as protective retreats, but which also create a unique microenvironment for sediment Bacteria and Archaea (Fig. 2a). Burrowing macrofauna species thereby alter the resource supply to sediment microbes and thus act as ecosystem engineers (Jones et al., 1994; Meysman et al., 2006). In the burrow microenvironment, microbes face (i) subsurface extensions of the oxic-anoxic interface, (ii) rich deposits of labile organic matter in the burrow wall, (iii) oscillating oxygen and DIN concentrations in the burrow lumen due to periodic ventilation activity by the animal, and (iv) pulses of ammonium excreted by the animal into the burrow lumen (Gardner et al., 1983; Kristensen et al., 1991; Papaspyrou et al., 2005; Stief and de Beer, 2006). This sequential or simultaneous presence of electron acceptors and donors in high concentration turns macrofauna burrows into "hot spots" of both aerobic and anaerobic microbial processes, such as the various $\mathrm{N}$-cycle pathways.

Outstanding taxonomic groups of benthic infauna that act as ecosystem engineers are chironomids, tubificids, and burrowing mayfly larvae in freshwater sediments as well as polychaetes, crustaceans, and mollusks in coastal marine sediments. A density-dependent stimulation of nitrogen cycling (i.e., an increase in process rates and solute fluxes in proportion to the population density of macrofauna) is reported for several prominent species: the insect Chironomus plumosus (Pelegri and Blackburn, 1996; Svensson, 1997, 1998; Stief et al., 2009), the oligochaete Tubifex tubifex (Svensson et al., 2001), the ragworm Nereis sp. (Bartoli et al., 2000), the mud shrimp Corophium sp. (Pelegri and Blackburn, 1994), and a number of other burrowing crustaceans (Webb and Eyre, 2004; D'Andrea and DeWitt, 2009; Jordan et al., 2009). Often, species with high ventilation rates have strong per capita impacts on the rates of $\mathrm{N}$-cycle pathways and the fluxes of DIN, especially when occurring at high in situ densities (Mayer et al., 1995; Svensson and Leonardson, 1996; Svensson et al., 2001; Nielsen et al., 2004). The highly abundant chironomid larvae, for instance, irrigate their burrows intermittently (Lewandowski et al., 2007; Roskosch et al., 2010) and thereby significantly stimulate sedimentary nitrification and denitrification and consequently the exchange of DIN across the sediment-water interface in lakes (Pelegri and Blackburn, 1996; Svensson, 1997, 1998; Stief and Hölker, 2006; Stief et al., 2009). Density-dependent stimulation of nitrogen cycling does not generally occur though. Denitrification may be stimulated in a density-dependent manner, but only until animal (and burrow) density significantly reduces the anoxic sediment volume between the burrows (Gilbert et al., 2003; Poulsen et al., 2013). Dunn et al. (2009) argue that the density-dependent stimulation of benthic metabolism observed in microcosm experiments is due to shifts in organic matter turnover, whereas under in situ conditions benthic metabolism is controlled to a larger degree by the rate of organic matter deposition. Emmerson et al. (2001) noted the biomass-dependent stimulation of ammonium efflux from intertidal sediments for a number of macrofauna species, but did not find a consistent pattern when single species were experimentally mixed to form multiple-species communities.

Stimulation of nitrification activity inside macrofauna burrows results from the enhanced availability of oxygen and ammonium due to the animal's ventilation and excretion activities, respectively (Mayer et al., 1995; Satoh et al., 2007). Consequently, the abundance of nitrifying Bacteria in the burrow walls is significantly higher than in the sediment surrounding the burrows (Satoh et al., 2007). Stimulation of denitrification activity inside macrofauna burrows results from the advective transport of oxygen and nitrate into the burrows during ventilation periods, followed by oxygen depletion and anaerobic nitrate consumption during resting 


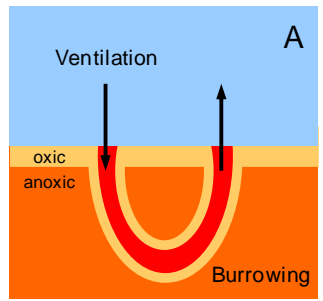

\author{
Ecosystem engineering by sediment infauna \\ - Physical-chemical alteration of habitat \\ - Extension of oxic-anoxic interface due to burrowing and ventilation \\ - Provision of dynamically oxic-anoxic microenvironments due to ventilation, respiration, and excretion \\ $\rightarrow$ Modified resource supply to sediment bacteria \\ $\rightarrow$ Enhanced organic matter mineralization, coupled nitrification-denitrification, and ammonium release
}

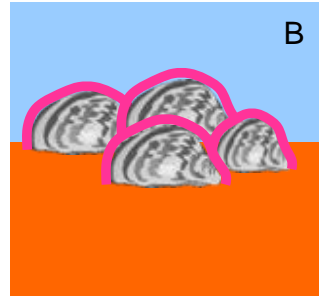

Ecosystem engineering by reef-building epifauna

- Physical-chemical alteration of habitat

- Extension of surface area for microbial colonization due to biogenic structures

- Enrichment of organic matter due to biodeposition

$\rightarrow$ Modified resource supply to benthic microorganisms

$\rightarrow$ Enhanced organic matter mineralization, nitrification and denitrification, and ammonium release

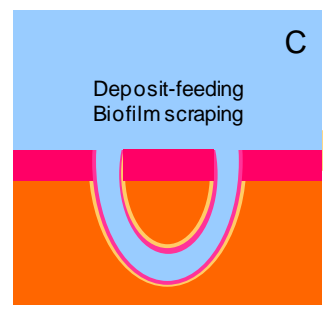

Grazing

- Ingestion of free-living and particle-attached bacteria

- Decline in abundance of slow-growing bacteria

- Decline in metabolic activity of grazing-sensitive bacteria

$\rightarrow$ Reduced nitrification activity at the sediment surface

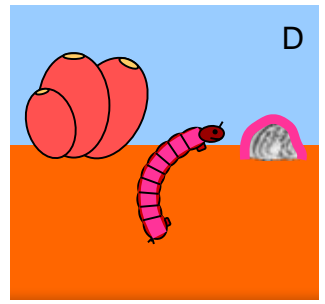

\title{
Symbiosis
}

- Intimate organismic association of bacteria and macrofauna in exoskeletal biofilms, gut contents, and soft tissues

- Provision of dynamically oxic-anoxic microenvironments within host organism

- Supply of metabolic waste products from host to symbiont

$\rightarrow$ Distinct benthic compartments for many different nitrogen cycle pathways

$\rightarrow$ Nitrous oxide production due to animal-associated nitrification and denitrification

Fig. 2. Three types of animal-microbe interactions that interfere with benthic nitrogen cycling in aquatic ecosystems: (A) and (B) ecosystem engineering, (C) grazing, and (D) symbiosis. The site of the microbial activity of interest is highlighted in pink (A): sediment burrow, (B): surface of biogenic reef structures, $(\mathbf{C})$ : sediment surface and burrow wall, (D): soft tissues, gut, and shell biofilm. Drawings of animals and biogenic structures are stylized and not to scale.

periods of the animals (Svensson, 1998). Additionally, denitrification activity inside burrows is coupled to nitrate and nitrite production by nitrification in the burrow walls, leading to a high relative contribution of coupled nitrificationdenitrification to total denitrification (Howe et al., 2004). The demand of denitrifying Bacteria and Archaea for electron donors is met by the labile organic matter that burrow walls are enriched with (Stief, 2007). Recently, the use of microsensors directly in the burrow lumen and the burrow wall has confirmed both the oscillating oxygen and DIN concentrations in ventilated burrows (Stief and de Beer, 2006; Stief et al., 2009) and the enhanced rates of nitrification and denitrification in the burrow walls (Nielsen et al., 2004; Stief et al., 2004; Satoh et al., 2007).

The possible net result of ventilation-enhanced solute exchange between water column and sediment depends on the ratio between rates of organic matter mineralization, ammo- nium excretion, nitrification, and denitrification inside the burrows. Many burrowing macrofauna species enhance (i) the net efflux of ammonium because rates of organic matter mineralization and ammonium excretion exceed the rate of nitrification (e.g., Pelegri and Blackburn, 1995; Svensson, 1997; Hansen and Kristensen, 1998; Stief and Hölker, 2006; Lewandowski et al., 2007) and (ii) the net influx of nitrate because the rate of denitrification exceeds the rate of nitrification (e.g., Pelegri and Blackburn, 1996; Nizzoli et al., 2007). However, ventilation-enhanced net efflux of nitrate by burrowing macrofauna is sometimes observed too (Christensen et al., 2000; D'Andrea and DeWitt, 2009). Additionally, several freshwater species enhance the efflux of nitrous oxide in a density-dependent manner (Svensson, 1998; Stief et al., 2009; Stief and Schramm, 2010; Poulsen et al., 2013). 


\subsubsection{Sediment epifauna}

Reef-building macrofauna species live in huge aggregations of individuals on top of soft and hard bottoms of shallow aquatic ecosystems and act as ecosystem engineers by altering the resource supply to other organisms (Jones et al., 1994; Markert et al., 2010) (Fig. 2b). In the reef structures, benthic microbes face (i) an extension of hard-substrate colonization surfaces, (ii) changed flow conditions and sedimentation rates, (iii) an enrichment of organic matter and ammonium due to macrofaunal biodeposition and excretion, respectively, and (iv) changed light and oxygen conditions due to water clearance through filter feeding by the reefbuilding organisms. As a consequence, macrofaunal reefs significantly affect microbially mediated nutrient dynamics in shallow aquatic ecosystems, including nitrogen cycling.

The world's largest biogenic reefs are the tropical coral reefs formed by colonial scleractinians (stony corals). Nitrogen cycling in coral reefs has amongst others been reviewed by O'Neil and Capone (2008) and by Fiore et al. (2010). However, effects of reef-building macrofauna on the microbial N-cycle are also reported for the bivalves Crassostrea sp. (oysters) and Mytilus sp. (blue mussels) in coastal marine ecosystems and Dreissena sp. (zebra mussels) in freshwater ecosystems. Crassostrea sp. (Dame et al., 1992; Gilbert et al., 1997; Souchu et al., 2001; Newell et al., 2002; Piehler and Smyth, 2011; Kellogg et al., 2013), Mytilus sp. (Prins and Smaal, 1994; Nizzoli et al., 2005; Stenton-Dozey et al., 2001), and Dreissena sp. (Gardner et al., 1995; Lavrentyev et al., 2000; Conroy et al., 2005; Bruesewitz et al., 2006; Bruesewitz et al., 2008; Svenningsen et al., 2012) have been shown to affect benthic DIN fluxes significantly. Additionally, Crassostrea gigas and Dreissena polymorpha have a very high potential for invading aquatic ecosystems, often with severe ecological and economic consequences (Pejchar and Mooney, 2009; Strayer, 2009; Higgins and Vander Zanden, 2010; Markert et al., 2010). However, Crassostrea sp. and Mytilus sp. cultivation is practiced in shellfish farming (Hatcher et al., 1994; Gilbert et al., 1997; Souchu et al., 2001; Nizzoli et al., 2005, 2006b) and exploited for ecosystem restoration by making use of their high filter-feeding activity (Newell et al., 2005; Plutchak et al., 2010; Higgins et al., 2011, 2013; Carmichael et al., 2012; Kellogg et al., 2013).

Bivalve reefs stimulate microbial nitrogen cycling through a combination of several mechanisms that mostly function at the level of the collective of the reef builders. The vast abundance of individuals confers a particular strength to the reef's effects on benthic DIN fluxes in shallow and constrained water bodies. Bivalve shells represent a wealth of hard substrata for colonization by biofilm-forming microbes (Gutierrez et al., 2003), including nitrifying and denitrifying microbes (Welsh and Castadelli, 2004; Heisterkamp et al., 2013). Nitrifying Bacteria and Archaea living in shell biofilms are nourished by metabolic waste products, such as ammonium and carbon dioxide, excreted by the reef-building organisms (Dame et al., 1992; Newell et al., 2002; Plutchak et al., 2010). Denitrifying Bacteria and Archaea benefit from the enrichment of labile organic matter in the reef due to biodeposition of suspended particles (i.e., seston) as mediated by the reef builders (Newell et al., 2005; Piehler and Smyth, 2011; Kellogg et al., 2013). Biodeposition of seston results from the filter-feeding activity by the bivalves followed by the production and enhanced sedimentation of feces and pseudofeces. Sedimentation and biodeposition of seston are further facilitated by low-flow areas within the surface relief of the reef (Lenihan, 1999). The filter-feeding activity by the bivalves also reduces phytoplankton densities, which leads to higher light penetration into the water body (Dame et al., 1992; Souchu et al., 2001; Newell et al., 2002). Since abundance and activity of benthic microalgae increase with enhanced light intensities, near-bed oxygen concentrations tend to be higher (Lenihan, 1999) and potentially stimulate coupled nitrification-denitrification (Souchu et al., 2001; Newell et al., 2002). In contrast, extremely high rates of biodeposition in long-line mussel farms reduce oxygen availability and nitrification activity in the underlying sediments (Nizzoli et al., 2005, 2006b; Carlsson et al., 2010). Fixed nitrogen removal from aquatic ecosystems via natural bivalve reefs or mussel farming is also achieved by harvesting the biomass (Newell et al., 2005, Higgins et al., 2011; Stadmark and Conley, 2011; Rose et al., 2012; Carmichael et al., 2012; Kellogg et al., 2013) or through predation by waterfowl (Hamilton et al., 1994).

\subsection{Grazing}

Benthic macrofauna species graze on microbes by filter feeding, deposit feeding, and scraping of biofilms. Typically, the ingested microbes are attached to sediment grains or detritus particles, or they are embedded in a biofilm matrix. Macrofaunal bacterivory has the potential to decrease the abundance of $\mathrm{N}$-cycle microbes and thereby also the rates of nitrification and denitrification (Fig. 2c). The advent of cultivation-independent methods to study individual cells, populations, and communities of microbes has made it possible to target specifically phylogenetic or functional groups of microbes directly in environmental samples. The abundance of Bacteria and Archaea involved in nitrification and denitrification, potentially reduced by macrofaunal grazing, can now be determined at the level of individual cells by FISH (Altmann et al., 2004) and at the level of gene abundance by quantitative polymerase chain reaction (PCR) targeting phylogenetic marker genes or functional genes (Dollhopf et al., 2005; Satoh et al., 2007; Gilbertson et al., 2012).

Isotopic evidence for macrofaunal grazing on sediment Bacteria and Archaea exists for freshwater and marine species (Levin and Michener, 2002; Deines et al., 2007; Pascal et al., 2008). This microbial diet provides, however, only a minor fraction of the carbon demand of benthic macrofauna (Kemp, 1987; Johnson et al., 1989; Goedkoop 
and Johnson, 1994; van Oevelen et al., 2006a). In turn, the grazing effect on total sediment Bacteria is quantitatively not important because benthic macrofauna species consume only a small fraction of the total bacterial production (Johnson et al., 1989; van de Bund et al., 1994; Pascal et al., 2008; van Oevelen et al., 2006b). Rapid regrowth of microbial populations apparently compensates for the losses caused by macrofaunal bacterivory (van de Bund et al., 1994; Plante and Wilde, 2001). Additionally, bacterivorous macrofauna species may even promote the regrowth of sediment Bacteria through ecosystem engineering.

Persistent grazing effects on sediment Bacteria only exist for bacterial groups that are efficiently eliminated by bacteriolysis in the animal gut and/or for those that show low growth rates in their benthic environment (Plante and Mayer, 1994; Altmann et al., 2004). Nitrifying Bacteria belong to the latter group and their abundance is indeed reduced in the depositfeeding layer of Chironomus riparius larvae (Altmann et al., 2004; Stief and de Beer, 2006). In the ventilation layer of the larvae, however, the total nitrifier abundance is higher than in control sediments, probably due to low grazing pressure and/or favorable growth conditions (Stief and de Beer, 2006). Thus, the direct effect of $C$. riparius larvae on the abundance of nitrifying Bacteria due to grazing is partially offset by indirect effects due to ecosystem engineering. In fact, nitrification rates were lower in the deposit-feeding layer of the larvae, while the total DIN fluxes between water column and sediment were not significantly different (Altmann et al., 2004). Several marine macrofauna species affect both the abundance ratio of archaeal to bacterial ammonia oxidizers and nitrification rates, but not the overall abundance of ammonia oxidizers (Gilbertson et al., 2012). Hence, grazing (probably together with ecosystem engineering) may alter the community structure of ammonia oxidizers and thereby affect nitrification rates. Persistent grazing effects on denitrifying Bacteria and Archaea have so far not been documented for aquatic sediments. It can be expected that this functional group of $\mathrm{N}$-cycle microbes will experience only a weak grazing pressure by macrofauna due to their subsurface occurrence and their generally high growth rates, but experimental evidence is currently lacking. Additionally, it has been shown that denitrifying Bacteria survive the gut passage when ingested by benthic macrofauna (Stief et al., 2009). In agreement with this finding, sediments inhabited or non-inhabited by $C$. plumosus larvae did not differ in the abundance of functional genes of denitrification (Poulsen et al., 2013).

Another effect of macrofaunal grazing on benthic Bacteria, Archaea, and microalgae might be the liberation of cellular pools of fixed nitrogen. Benthic diatoms, a major food component of deposit-feeding macrofauna species (e.g., Evrard et al., 2012), are known to store nitrate intracellularly at concentrations exceeding ambient levels by several orders of magnitude (Kamp et al., 2011, Stief et al., 2013). It can be speculated that the intracellular nitrate pool of diatoms will burst out when the cells lyse in the gut of macro- faunal grazers. The fate of this liberated nitrate is so far entirely unknown. In contrast, ecosystem engineering by Nereis (Hediste) diversicolor has been shown to increase the intracellular nitrate contents of benthic microalgae as a consequence of increased nitrate availability in the sediment due to stimulated nitrification (Heisterkamp et al., 2012).

\subsection{Symbiosis}

The body of benthic macrofauna features permanent or transient habitats for Bacteria, Archaea, and other microbes. Hard body surfaces may carry microbial biofilms, soft tissues may host cellular and extracellular symbionts, and guts constitute transient habitats for ingested microbes or permanent habitats for symbionts of the gut wall (Fig. 2d). While such intimate organismic associations can loosely be termed symbioses (as is done here), the functional relationship between the macrofaunal and the microbial partners may in reality range from parasitism via commensalism to symbiosis. Very often, however, the type of functional relationship is not known and additionally smooth transitions exist between the different types. This review covers intimate associations of benthic macrofauna and $\mathrm{N}$-cycle microbes located in exoskeletal biofilms, gut contents, and the soft tissues of the animal (Fig. 2d). As a common trait of these associations, the microbial metabolism is mainly controlled by the substrates, nutrients, and microenvironmental conditions provided by the animal host (McFall-Ngai et al., 2013). Nitrogen cycling mediated by symbionts of benthic macrofauna is thus partially uncoupled from the ambient supply of DIN and oxygen.

\subsubsection{Exoskeletal biofilms}

Benthic macrofauna species with a hard body surface (e.g., a chitinous exoskeleton or a calcareous shell) are often colonized by microbes organized in biofilms (Wahl et al., 2012). Usually, these exoskeletal biofilms develop better in epifaunal species, such as reef-building bivalves, because of lower abrasion forces in the water column than in the sediment. Aside from mollusks (e.g., bivalves and gastropods), higher crustaceans and ascidians are reported to carry biofilms on their body surface (Heisterkamp et al., 2010). Exoskeletal biofilms of a number of marine species harbor nitrifying Bacteria and Archaea that are nourished by ammonium and carbon dioxide excreted by the animal host (Welsh and Castadelli, 2004; Welsh et al., 2009). The nitrification activities associated with abundant macrofauna species contribute to overall benthic nitrification rates aided by the efficient solute exchange between the biofilms and the ambient water (Welsh and Castadelli, 2004). Additionally, the shell biofilms of freshwater and marine mollusks produce substantial amounts of nitrous oxide via both nitrification and denitrification (Svenningsen et al., 2012; Heisterkamp et al., 2013). 


\subsubsection{Gut contents}

Microbes ingested by macrofauna are not necessarily digested and may in fact survive and remain metabolically active during the gut passage (Plante and Mayer, 1994). Furthermore, the gut microenvironment may induce metabolic pathways of the microbes that are not active in their natural environment. As shown by microsensor measurements, the gut interior of many species is anoxic (Plante and Jumars, 1992; Stief and Eller, 2006; Stief et al., 2009), which even applies to relatively small marine zooplankton (Tang et al., 2011). Microbes that normally live in oxic environments will thus experience a shift from oxic to anoxic conditions when ingested by filter- or deposit-feeding macrofauna. This oxicanoxic shift induces denitrification activity in facultatively anaerobic microbes, which then start producing nitrous oxide and dinitrogen, gases that are efficiently emitted from the gut and the animal (Stief et al., 2009). Nitrate obviously enters the gut when water-soaked food particles are ingested (Stief et al., 2010). Not all macrofauna species emit nitrous oxide though, some because they are predators and only ingest few microbes (Stief and Schramm, 2010), while others do not emit nitrous oxide because of bacteriolytic activities in the gut (Plante and Mayer, 1994; Heisterkamp et al., 2010).

\subsubsection{Soft tissues}

Sponges are engaged in symbioses with diverse microbes (Hentschel et al., 2006; Fiore et al., 2010; Webster and Taylor, 2012). The environmental importance of spongemicrobe symbioses is due to the often high coverage of benthic habitats with sponges and their ability to process large volumes of ambient water. The periodic ventilation activity of sponges causes dynamic changes between oxic and anoxic conditions inside the tissues (Schläppy et al., 2007, 2010b; Hoffmann et al., 2008). Consequently, both aerobic and anaerobic $\mathrm{N}$-cycle pathways can be active in the same host organism in different body sections or at different times (Fiore et al., 2010). Some of the bacterial and archaeal symbionts of sponges fix dinitrogen and supply the host and possibly the nutrient-poor environment with fixed nitrogen (Weisz et al., 2007; Fiore et al., 2012). Several sponge species exhibit nitrification activity due to symbiotic ammonia-oxidizing Bacteria and Archaea that obviously benefit from ammonium and carbon dioxide excreted by the sponge (Jimenez and Ribes, 2007; Bayer et al., 2008; Hoffmann et al., 2009; Schläppy et al., 2010a; Radax et al., 2012a). Consequently, nitrate excretion has been observed in the sponge Aplysina aerophoba, albeit at rates considerably lower than ammonium excretion (Bayer et al., 2008). In contrast, the sponge Geodia barretti constitutes a nitrate sink due to its high denitrification and anammox activities (Hoffmann et al., 2009). Additionally, this sponge harbors active ammonia-oxidizing Bacteria and Archaea as demonstrated by metatranscriptomics (Radax et al., 2012b). In coastal ma- rine ecosystems with high sponge cover, the extrapolated rates of sponge-mediated $\mathrm{N}$-cycle pathways rival those measured in ambient sediments (Jimenez and Ribes, 2007; Hoffmann et al., 2009).

Nitrate reduction activity is also associated with marine tube worms and nematodes, but the extent of their nitrate exchange with the water column is currently not known. In the trophosome of the tube worm Riftia pachyptila, intracellular symbionts reduce nitrate to nitrite and/or ammonium, which may serve respiratory or assimilatory purposes (Hentschel and Felbeck, 1993; Girguis et al., 2000). For two marine nematode species, nitrate reduction to nitrite mediated by symbionts attached to the worms' cuticle was demonstrated (Hentschel et al., 1999). It was speculated that such ectosymbionts associated with the marine nematode Robbea sp. use nitrate in the absence of oxygen to oxidize sulfide (Bayer et al., 2009). These forms of symbiosis-derived nitrate reduction, if widespread in nematodes, could be environmentally important because of the high abundance of nematodes in coastal marine sediments. Dedicated research is needed to quantify the potential contribution of benthic nematodes to microbial nitrogen cycling.

Many more symbiotic associations exist that involve Nconversions by the microbial symbiont and $\mathrm{N}$-transfer to the host animal, such as bacterial nitrogen fixation in shipworms and bivalves (Lechene et al., 2007) and corals (Fiore et al., 2010), archaeal ammonia oxidation in colonial ascidians (Martinez-Garcia et al., 2008), and bacterial regeneration of nitrogenous waste products in leeches (Kikuchi et al., 2009). The environmental significance of these highly specific symbioses is probably low because of the efficient transfer of substrates and nutrients between the symbiotic partners and because in many cases the microbial symbionts are phagocytosed by the host animal.

\section{Ecosystem-level impact of animal-microbe interactions}

\subsection{Fixed nitrogen removal}

\subsubsection{Evaluation criteria}

The results of 39 published studies were quantitatively evaluated with respect to ecosystem-level fixed nitrogen removal (Fig. 3, Tables 1 and 2). The majority of studies found suitable for this evaluation were conducted as laboratory experiments in which the density of a single macrofauna species was manipulated, despite the fact that benthic communities may comprise many different macrofauna species. Such use of mono-species experiments is justified when the given species occurs at extremely high density and dominates the macrofauna community. Additionally, in many of the selected studies, only a single type of animal-microbe interactions (the most popular one being "ecosystem engineering 

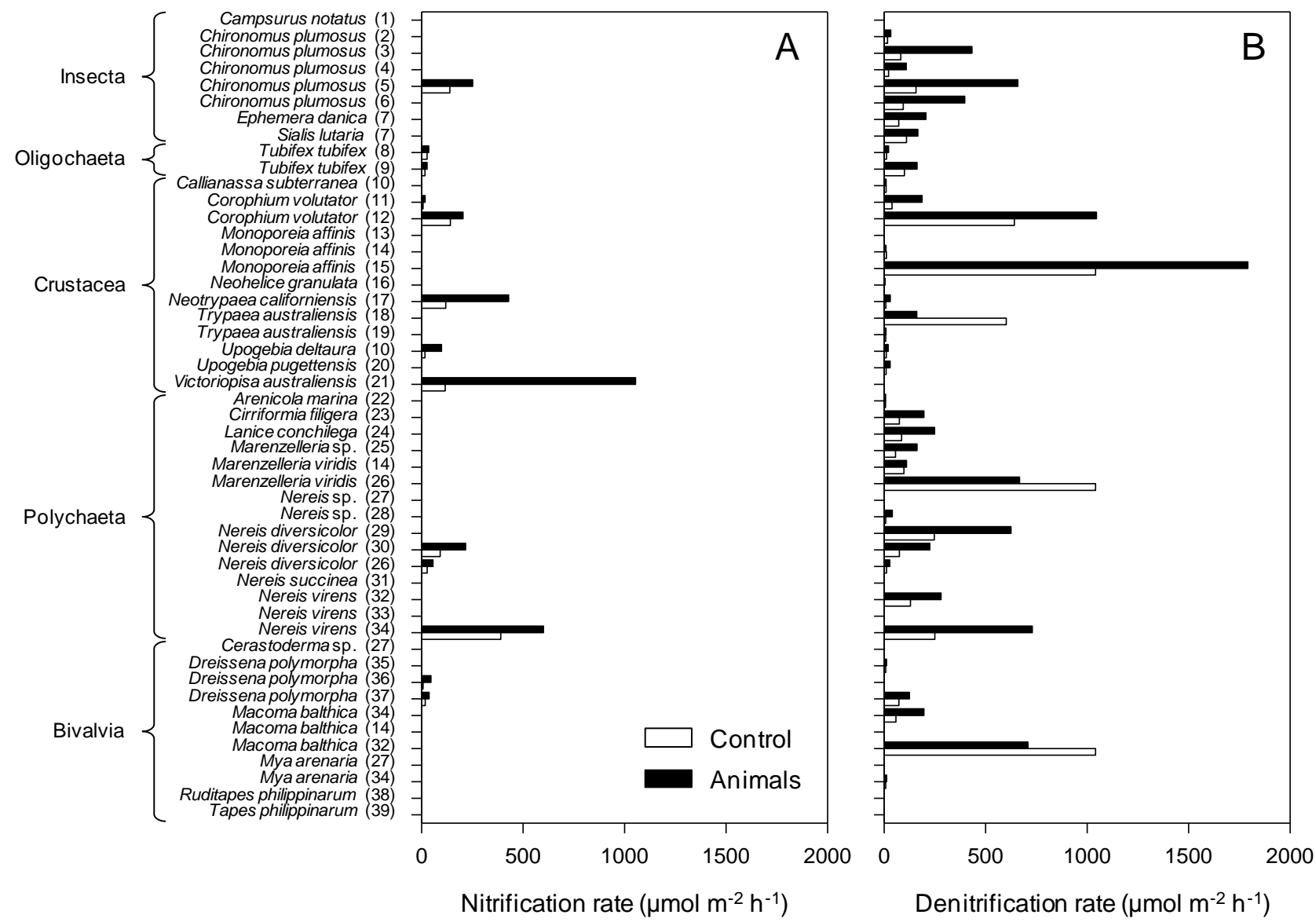

Fig. 3. Data from 39 published studies in which (A) nitrification rates, (B) denitrification rates, (C) ammonium fluxes, and (D) nitrate fluxes were compared between sediment with and without single macrofauna species. Data were extracted from tables, figures, and text of studies that are indexed together with environmental and experimental settings in Table 2. Average rates and fluxes are given for sediment without macrofauna (control) and sediment with the highest density of macrofauna (animals) and were re-calculated to $\mu \mathrm{mol} \mathrm{N} \mathrm{m} \mathrm{m}^{-2} \mathrm{~h}^{-1}$. Positive fluxes are directed from sediment to water, negative fluxes from water to sediment. No bar is displayed when information was not available. Variation of data is found in the original references (numbers in parentheses).

by sediment infauna") is discussed. In reality, these studies address the net effect of several types of animal-microbe interactions that may run in parallel, both within single macrofauna species and within macrofauna communities.

Figure 3 displays taxonomically grouped macrofauna species for which at least one of the following variables was determined: nitrification and denitrification rates, and ammonium and nitrate fluxes. Denitrification rates correspond to (i) the sum of rates of coupled nitrification-denitrification $\left(D_{\mathrm{n}}\right)$ and denitrification of water column nitrate $\left(D_{\mathrm{w}}\right)$ when the isotope pairing technique (Nielsen, 1992) or the $\mathrm{N}_{2} /$ Argon technique was used (Kana et al., 1994), or to (ii) $D_{\text {w }}$ alone when the acetylene inhibition technique was used (Sørensen, 1978). The latter is because acetylene also inhibits nitrification (i.e., $D_{\mathrm{n}}=0$ ), and thus the total rate of denitrification is underestimated.

Only a selected subset of data from the screened studies can be presented here, which will certainly bias the over- all outcome of the quantitative evaluation. For instance, the macrofauna density closest to the natural density (if mentioned in the original reference), one out of several sediment types or incubation temperatures tested (if such comparisons were made), and the end point of time-series experiments (if temporal aspects were investigated) were considered. Note also that even within a single macrofauna species, the variability of results was often substantial, probably due to differences in animal density, sediment type, incubation length, DIN concentration, temperature, and analytical procedures used. For these reasons, the possible influence of environmental and experimental settings (e.g., sediment reactivity, incubation conditions) on the outcome of the quantitative evaluation was also tested. 


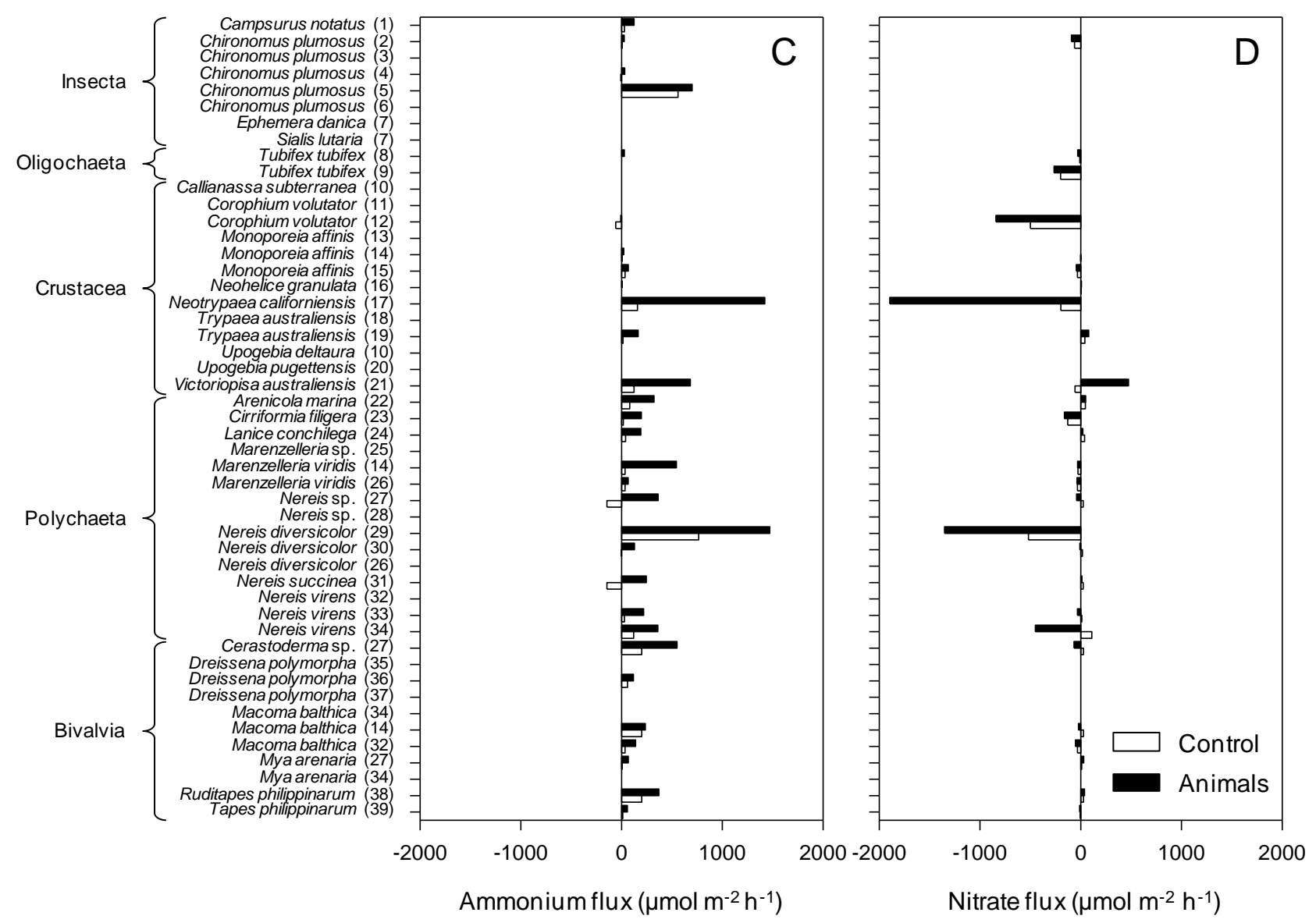

Fig. 3. Continued.

\subsubsection{Overview}

Freshwater macrofauna is represented by the classes Insecta, Oligochaeta, and Bivalvia, while marine macrofauna is represented by the classes Crustacea, Polychaeta, and Bivalvia (Fig. 3). Freshwater insects and oligochaetes were tested at densities of 2000-38750 individuals $\mathrm{m}^{-2}$. Prominent examples occurring at such high densities in lake sediments are Chironomus plumosus and Tubifex tubifex. The presence of all insect and oligochaete species increased the areal rates of nitrification and denitrification, the ammonium efflux, and the nitrate influx. In the only two studies in which both ammonium and nitrate fluxes were measured (i.e., C. plumosus (Pelegri and Blackburn, 1996) and T. tubifex (Pelegri and Blackburn, 1995b)), the animal-enhanced nitrate influx at least balanced or even exceeded the ammonium efflux.

Crustacean species tested comprise both small amphipods (e.g., Corophium volutator) and large decapods (e.g., Callianassa subterranea) and burrow in coastal marine sediments at densities of 30-19800 individuals $\mathrm{m}^{-2}$. All crustacean species increased nitrification rates, in the extreme case ca. 10-fold (Upogebia pugettensis; D'Andrea and DeWitt, 2009), but only about half of them increased denitri- fication rates (e.g., $C$. volutator), while the other half had no significant effect on denitrification (e.g., C. subterranea). The presence of decapods strongly increased the ammonium efflux (e.g., Neohelice granulata; Fanjul et al., 2011), while amphipods only had a minor effect on the ammonium flux with the exception of Victoriopisa australiensis (Dunn et al., 2009). Crustacean effects on nitrate fluxes were diverse, ranging from strong increases of the nitrate influx observed for C. volutator (Pelegri et al., 1994; Pelegri and Blackburn, 1994) and N. granulata (Fanjul et al., 2011) to increases of the nitrate efflux observed for Trypaea australiensis (Jordan et al., 2009) and U. pugettensis (D'Andrea and DeWitt, 2009). In studies in which both ammonium and nitrate fluxes were measured, the animal-enhanced ammonium efflux often exceeded the nitrate influx, but in five studies the presence of crustaceans increased the simultaneous efflux of ammonium and nitrate.

Bivalves are the only class for which both freshwater and marine species were tested (at densities of 440-10000 individuals $\mathrm{m}^{-2}$ ) for their effects on benthic nitrogen cycling. The presence of the invasive Dreissena polymorpha increased nitrification rates (Lavrentyev et al., 2000; 
Bruesewitz et al., 2008), but no other bivalve species was tested for this trait. Nearly all bivalve species increased denitrification rates, but in some cases only marginally (e.g., Tapes philippinarum; Nizzoli et al., 2006b); in the presence of Macoma balthica (Karlson et al., 2005), denitrification rates were even lower than in their absence. Ammonium effluxes were consistently enhanced by bivalves, with T. philippinarum (Nizzoli et al., 2006b) having the strongest effect. Nitrate fluxes were influenced in diverse ways, even within one species (i.e., M. balthica; Karlson et al., 2005; Henriksen et al., 1983; Michaud et al., 2006), covering increases of the nitrate influx, increases of the nitrate efflux, and an inversion of the flux direction. In studies in which both ammonium and nitrate fluxes were measured, the absolute increase in ammonium efflux was always larger than any change in nitrate flux.

Marine polychaetes were tested at densities of 50-5000 individuals $\mathrm{m}^{-2}$. Nitrification rates were increased in the presence of two Nereis species (Hansen and Kristensen, 1998; Nielsen et al., 2004; Kristensen et al., 1991) and not tested for any other polychaete species. With one exception (i.e., Marenzelleria viridis; Karlson et al., 2005), all polychaete species, including $M$. viridis tested in two other studies (Hietanen et al., 2007; Kristensen et al., 2011), increased denitrification rates often ca. 3-fold. Without exception, the presence of marine polychaetes increased the ammonium efflux, in some cases more than 10-fold (e.g., Marenzelleria sp.; Hietanen et al., 2007). All polychaete species increased the nitrate influx (e.g., Nereis sp.; Nizzoli et al., 2006b) or led to the inversion of a nitrate efflux to a nitrate influx (e.g., N. virens; Henriksen et al., 1983; Kristensen et al., 1991; Michaud et al., 2006). In almost all studies in which both ammonium and nitrate fluxes were measured, the absolute increase in ammonium efflux was larger than the increase in nitrate influx.

\subsubsection{Synthesis}

The general patterns of macrofauna-induced stimulation of benthic nitrogen cycling are compiled in Table 1. On average, the presence of abundant benthic macrofauna species increased the areal rates of nitrification and denitrification by factors of $3.0 \pm 2.3(n=15)$ and $2.4 \pm 1.5(n=39)$, respectively (Table 1). Ammonium effluxes and nitrate influxes were on average enhanced by factors of $5.3 \pm 4.1$ $(n=26)$ and $2.2 \pm 2.2(n=14)$, respectively. Thus, while both nitrification and denitrification were stimulated to approximately the same degree, the stimulation of the ammonium efflux was considerably stronger than the stimulation of the nitrate influx.

Stimulation factors alone may not be representative measures of changes in DIN concentrations in the water column when background rates and fluxes differ largely. Therefore, it is also necessary to look at the absolute changes in ammonium and nitrate fluxes imposed by benthic macrofauna (Table 1). On average, the ammonium efflux was enhanced by $235 \pm 285 \mu \mathrm{mol} \mathrm{N} \mathrm{m}{ }^{-2} \mathrm{~h}^{-1}(n=31)$, while the nitrate influx was only enhanced by $118 \pm 381 \mu \mathrm{mol} \mathrm{N} \mathrm{m} \mathrm{N}^{-2} \mathrm{~h}^{-1}(n=28)$. Thus, the removal of fixed nitrogen from the water column as nitrate (via animal-enhanced denitrification) is more than offset by the increase in fixed nitrogen as ammonium (via animal-enhanced solute transport). Against this background, it is not surprising that the DIN efflux from the sediments used in the 39 studies increased on average from 24 to $162 \mu \mathrm{mol} \mathrm{N} \mathrm{m}{ }^{-2} \mathrm{~h}^{-1}(n=27)$ when benthic macrofauna was present.

Sources of bias in this quantitative evaluation are (i) the vastly different background rates and fluxes, (ii) the different experimental conditions imposed on sediments and animals, and (iii) the different subsets of data provided by the individual studies (i.e., the number of observations differs between the variables). The stimulation factors obtained for nitrification and denitrification rates and for ammonium and nitrate fluxes are nevertheless quite robust. Correlations between these factors and proxies of sediment reactivity (i.e., water depth, ammonium efflux) or experimental conditions (i.e., nitrate amendment, incubation temperature) were not observed (Fig. S1). Likewise, the stimulation factors did not differ significantly when separately calculated for marine vs. freshwater sediments, different methods used for process rate analysis, and intact vs. sieved sediments (Fig. S2). Stimulation factors are by nature (they are quotients) not affected by normalization to variables like ammonium efflux, nitrate concentration, or incubation temperature (Table S1). The variation in the stimulation factors seen in Table $\mathrm{S} 1$ is only due to the fact that normalization is not applicable to studies for which the variable used for normalization is not reported (i.e., a different subset of studies is incorporated in the calculation of the stimulation factors). The enhancement values calculated for absolute changes in solute fluxes are affected by the same phenomenon (i.e., different subsets of studies are considered for the calculation of normalized data), but here normalization might also generally change the absolute enhancement values. As can be seen in Table S1, however, the general trends reported above remain the same for these data, even when normalized for parameters of sediment reactivity and experimental conditions.

\subsection{Nitrous oxide emission}

Fixed nitrogen removal due to macrofauna activities is counteracted not only by the enhanced ammonium efflux from the sediment into the water column, but also by enhanced nitrous oxide emission. This phenomenon has first been noted for the ubiquitous and highly abundant freshwater midge larva C. plumosus (Svensson, 1998) and thereafter for many other freshwater and marine macrofauna species (Stief et al., 2009; Heisterkamp et al., 2010). Svensson (1998) ascribed the emission of nitrous oxide from lake sediment colonized by $C$. plumosus to nitrification activity inside the larval burrows. Stief et al. (2009) discovered nitrous oxide production due to denitrification activity inside the gut of $C$. plumosus 
Table 1. Macrofauna-induced stimulation of benthic nitrification and denitrification and of ammonium and nitrate fluxes across the sedimentwater interface.

\begin{tabular}{|c|c|c|c|c|c|c|c|c|}
\hline & \multicolumn{4}{|c|}{$\begin{array}{l}\text { Stimulation factor } \\
(x \text {-fold })\end{array}$} & \multicolumn{2}{|c|}{$\begin{array}{l}\text { Absolute change of flux } \\
\quad\left(\mu \mathrm{mol} \mathrm{N} \mathrm{m} \mathrm{m}^{-2} \mathrm{~h}^{-1}\right)\end{array}$} & \multicolumn{2}{|c|}{$\begin{array}{c}\text { Total DIN flux } \\
\left(\mu \mathrm{mol} \mathrm{N} \mathrm{m}^{-2} \mathrm{~h}^{-1}\right)\end{array}$} \\
\hline & Nitrification & Denitrification & $\mathrm{NH}_{4}^{+}$-Flux & $\mathrm{NO}_{3}^{-}$-Flux* & $\mathrm{NH}_{4}^{+}-$Flux $^{* *}$ & $\mathrm{NO}_{3}^{-}$-Flux ${ }^{* *}$ & Control & Animals \\
\hline Minimum & 1.0 & 0.3 & 0.1 & 0.3 & +5 & -1698 & -558 & -850 \\
\hline Maximum & 9.0 & 7.0 & 15.4 & 9.6 & +1263 & +530 & +246 & +1156 \\
\hline Average & 3.0 & 2.4 & 5.3 & 2.2 & +235 & -18 & +24 & +162 \\
\hline SD & 2.3 & 1.5 & 4.1 & 2.2 & 285 & 381 & 158 & 372 \\
\hline$n$ & 15 & 39 & 26 & 14 & 31 & 28 & 27 & 27 \\
\hline
\end{tabular}

Stimulation factors, absolute changes of fluxes, and total DIN fluxes were calculated based on the data presented in Fig. 3 . The number of studies ( $n$ ) varies between the different factors because each study provided a different subset of information. Overall average and standard deviation (SD) were calculated from average values presented in the original studies, thus neglecting the propagation of uncertainty. ${ }^{*}$ These stimulation factors were calculated for cases in which the $\mathrm{NH}_{4}^{+}$-flux was directed out of the sediment ( $n=26$ studies), and the $\mathrm{NO}_{3}^{-}$-flux was directed into the sediment ( $n=14$ studies) in both the presence and absence of macrofauna. ** The absolute change of flux is the difference between fluxes in the presence and absence of macrofauna, irrespective of the direction of the individual fluxes.

larvae and other filter- and deposit-feeding freshwater macrofauna. Heisterkamp et al. (2010) additionally found nitrous oxide production occurring in the biofilm covering the shell of a marine snail. In the same study, the highest animalassociated nitrous oxide emission rate measured so far was shown to be due to nitrous oxide production in both gut contents and exoskeletal biofilms of the aquacultured shrimp Litopenaeus vannamei. In summary, nitrous oxide production can be (i) indirectly associated with benthic macrofauna and mediated by microbes in their immediate microenvironment (e.g., their burrow) and/or (ii) directly associated with benthic macrofauna and mediated by microbes in their guts or their shell biofilms. The first case fits into the category ecosystem engineering, while the second case fits into the categories grazing and symbiosis.

Emission of nitrous oxide produced in the burrows and guts of $C$. plumosus larvae and other sediment-dwelling macrofauna is greatly facilitated by burrow ventilation. At a density of 745 individuals $\mathrm{m}^{-2}$, for instance, C. plumosus transports $1300 \mathrm{~L} \mathrm{~m}^{-2} \mathrm{~d}^{-1}$ lake water through the sediment by burrow ventilation (Roskosch et al., 2010). Thereby, the larvae simultaneously enhance the nitrate influx into the sediment (potentially stimulating denitrification in burrows and guts) and the ammonium and nitrous oxide effluxes from the sediment. Approximately $15-30 \%$ of the increased nitrous oxide emission is due to gut denitrification, while the remainder is due to stimulated nitrification and denitrification in C. plumosus burrows (Svensson, 1998; Stief et al., 2009). The nitrous oxide yield of gut denitrification (i.e., the $\mathrm{N}_{2} \mathrm{O} / \mathrm{N}_{2}+\mathrm{N}_{2} \mathrm{O}$ emission ratio) is $43-68 \%$ and thus significantly higher than the $0.1-0.5 \%$ reported for aquatic sediments (Seitzinger and Kroeze, 1998; Stief et al., 2009, 2010). The high nitrous oxide yields are explained by incomplete induction of the denitrification sequence or by partial inhibition of the nitrous oxide reduction step by low oxygen concentrations. At a density of 3450 individuals $\mathrm{m}^{-2}, C$. plumosus larvae increase the nitrous oxide yield of sediment-water gas fluxes ca. 2.5-fold (Stief et al., 2009). Nitrous oxide fluxes of
$1-8 \mu \mathrm{mol} \mathrm{N} \mathrm{m} \mathrm{m}^{-2} \mathrm{~h}^{-1}$ were measured in lake sediment inhabited by different densities of $C$. plumosus in which areal denitrification rates were as high as $200-800 \mu \mathrm{mol} \mathrm{N} \mathrm{m}^{-2} \mathrm{~h}^{-1}$ (Poulsen et al., 2013). In contrast, Svensson (1998) measured maximum nitrous oxide fluxes of only $0.45 \mu \mathrm{mol} \mathrm{N} \mathrm{m}{ }^{-2} \mathrm{~h}^{-1}$ in lake sediment in which areal nitrification and denitrification rates were 250 and $200-650 \mu \mathrm{mol} \mathrm{N} \mathrm{m}{ }^{-2} \mathrm{~h}^{-1}$, respectively. Aside from C. plumosus, only two more sedimentdwelling freshwater species have been studied: the mayfly Ephemera danica and the alderfly Sialis lutaria (Stief and Schramm, 2010). C. plumosus and E. danica larvae contribute to the total nitrous oxide efflux by gut denitrification and by stimulating sedimentary denitrification, while $S$. $l u$ taria only stimulates sedimentary denitrification. E. danica and $S$. lutaria enhanced areal rates of nitrous oxide emission from stream sediment from 0.16 to 0.41 and from 0.35 to $1.63 \mu \mathrm{mol} \mathrm{N} \mathrm{m} \mathrm{N}^{-1}$, respectively (Stief and Schramm, 2010). In summary, these examples indicate that nitrous oxide emission enhanced by sediment infauna apparently is not a major route of fixed nitrogen removal from aquatic ecosystems, but may rather be of importance in the context of climate change.

A recent study revealed that the invasive bivalve $D$. polymorpha potentially increases the nitrous oxide efflux 400 3000-fold at natural densities of 100 000-700000 individuals $\mathrm{m}^{-2}$ (Svenningsen et al., 2012). This corresponds to a very high potential areal nitrous oxide emission rate of $>28 \mu \mathrm{mol} \mathrm{N} \mathrm{m}{ }^{-2} \mathrm{~h}^{-1}$ (Svenningsen et al., 2012), which falls within the range of areal denitrification rates reported in a number of studies (Table 1). One third of the nitrous oxide emitted by $D$. polymorpha is produced in the shell biofilm as a by-product of ammonia oxidation; the remaining two thirds are produced in the gut as an intermediate of denitrification. The high rate of ammonium excretion by $D$. polymorpha (Conroy et al., 2005) thus fuels not only coupled nitrification-denitrification in the sediment (Bruesewitz et al., 2008), but also the nitrous-oxide-producing $\mathrm{N}$-cycle microbes in the biofilm on their own shell. Meanwhile, also 


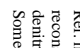

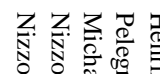

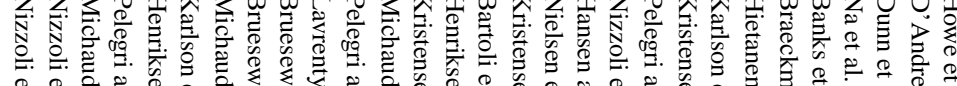

$\begin{array}{lll} & \\ 0\end{array}$

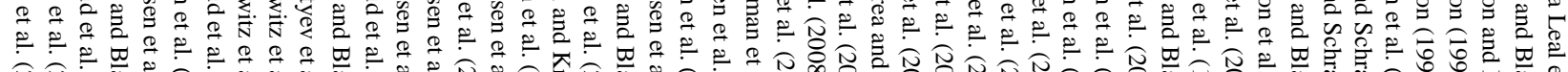

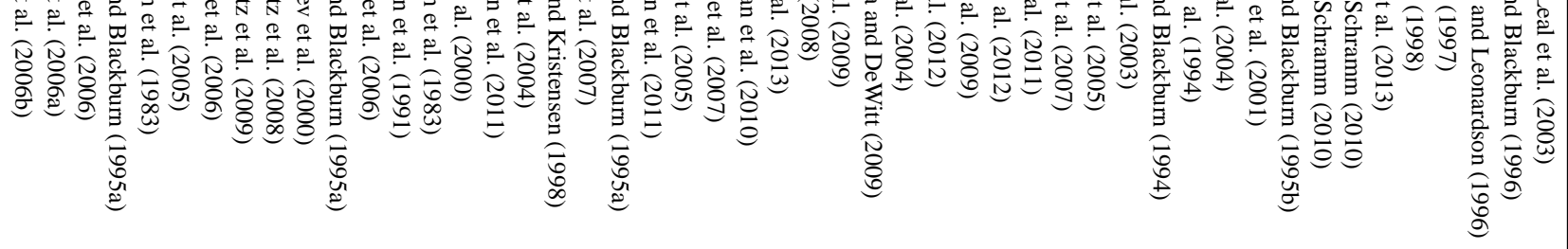

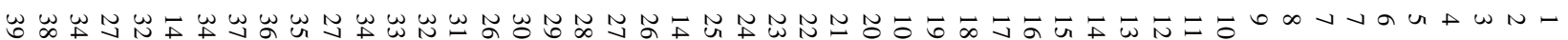

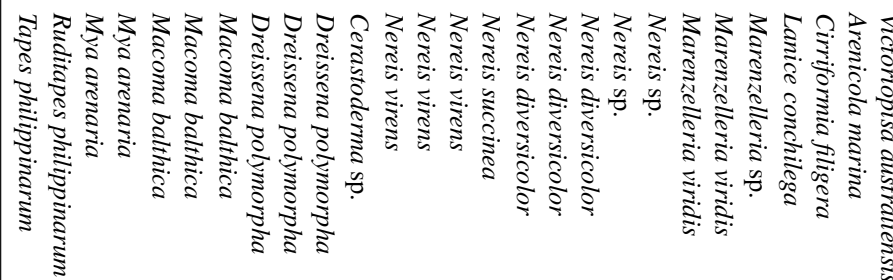
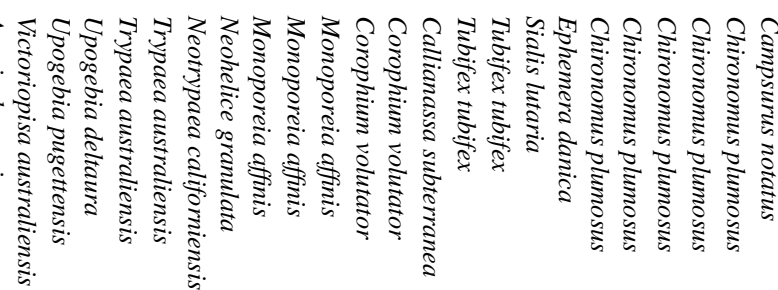

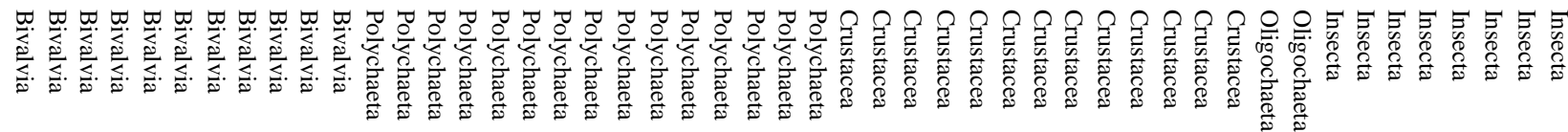

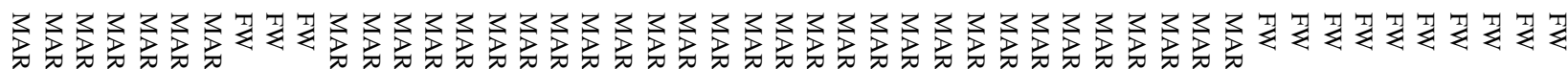

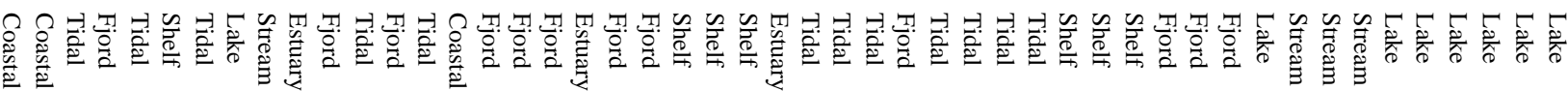

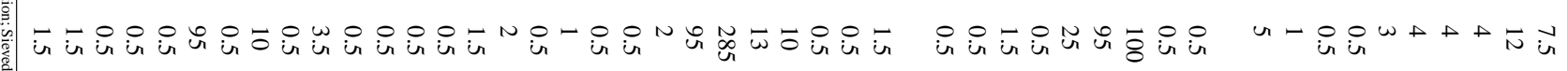

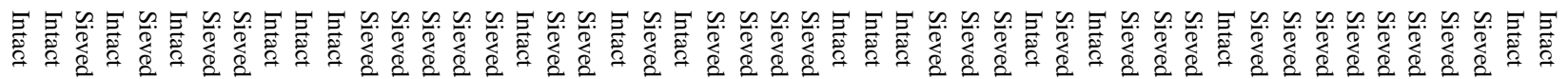

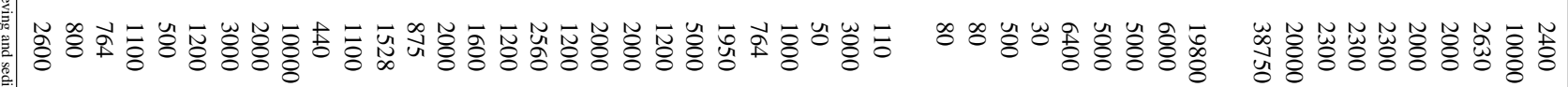

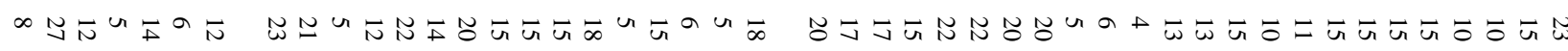
w

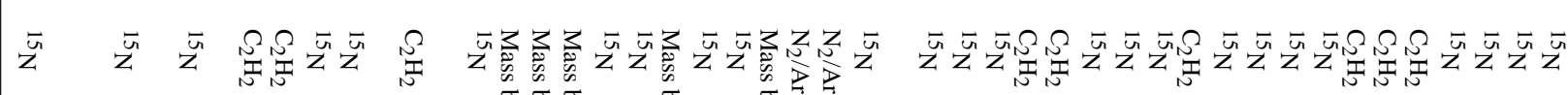

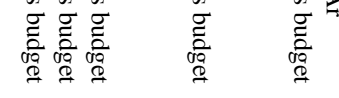


marine mollusks were found to emit nitrous oxide produced in their shell biofilm by both nitrification and denitrification (Heisterkamp et al., 2013), but areal emission estimates are still missing. Ammonium excretion rates of the animal hosts were by far higher than the rates of nitrous oxide emission from the shell biofilms, meaning that nitrous oxide production may be uncoupled from ambient DIN supply. Additionally, the nutrient-rich microenvironment shapes specific microbial communities, since nitrous oxide emission rates from living animals with shell biofilms are higher than from stones or shell debris collected nearby (Heisterkamp et al., 2013).

\section{Conclusions and perspectives}

In the last two decades, the focal points in studying the stimulation of nitrogen cycling by benthic macrofauna were (i) sediment infauna as players, (ii) ecosystem engineering as mechanism, and (iii) fixed nitrogen removal and nitrogen regeneration as ecosystem-level effects. This review tries to provide a more complete picture of animal-microbe interactions in aquatic ecosystems that are impacted by excess fixed nitrogen. For this purpose, the so far neglected contributions by (i) benthic epifauna, (ii) grazing and symbiosis, and (iii) animal-associated nitrous oxide production were conceptually integrated. Additionally, a large number of published studies were quantitatively analyzed to arrive at more general trends in animal-mediated stimulation of process rates and solute fluxes.

Benthic epifauna species provide a wealth of hard substrata for colonization by biofilm-forming microbes, while infauna species provide dynamic oxic-anoxic interfaces for sediment microbes. Exoskeletal biofilms of epifauna significantly contribute to benthic nitrification and nitrous oxide emission through a kind of animal-microbe symbiosis. Nitrogen cycling in these biofilms may be uncoupled from ambient nutrient availability because the animal host supplies ammonium to the biofilms at high rates. In contrast, ecosystem engineering by benthic infauna stimulates nitrification and denitrification rates as well as nitrate and ammonium fluxes and thereby ecosystem-level fixed nitrogen removal and/or nitrogen regeneration. The quantitative analysis in this review reveals that the stimulation of the ammonium efflux by benthic infauna is disproportionally high, which questions reports on enhanced fixed nitrogen removal in the presence of benthic macrofauna. The proximate cause for this observation is animal-enhanced solute transport that allows ammonium to cross the nitrification layer, which in diffusive settings acts as an efficient barrier for ammonium. Ultimate causes are biodeposition of organic matter by feeding activities, enhanced organic matter mineralization through ventilation-induced redox oscillations in the sediment, and excretion of ammonium by benthic macrofauna. Animalenhanced solute transport also increases the total flux of nitrate between water column and sediment. However, the turnover time of nitrate may well exceed its residence time in hypoxic or anoxic sediment compartments in which dissimilatory nitrate reduction occurs. Consequently, nitrate is transported back into the water column before it has been completely consumed in the sediment, which is supported by recent microsensor measurements in macrofauna burrows.

Stimulating effects by grazing on microbes and by symbiosis with microbes on benthic nitrogen cycling have so far been poorly investigated. Molecular, cultivation-independent techniques for analyzing microbial communities can now be used to follow grazing on biofilm and sediment Bacteria and Archaea, even in the gut of macrofauna. Likewise, symbionts in exoskeletal biofilms, soft tissues, and the gut can be analyzed with molecular techniques. Even the presence and expression of functional genes involved in N-cycle pathways can be determined, which will allow conclusions on grazing and symbiosis effects on the stimulation of nitrogen cycling by macrofauna. To date, at least the role of symbiosis has partially been unraveled with respect to animal-associated nitrogen turnover. Both exoskeletal biofilms of mollusks and gut microbes of various macrofauna species were shown to produce significant amounts of nitrous oxide. Epifauna species, especially in intertidal zones, emit nitrous oxide directly into the water column or the atmosphere. In contrast, nitrous oxide emitted by infauna species may only partially reach the water column and the atmosphere because of microbial turnover of nitrous oxide in the sediment surrounding the burrow.

Based on the data available to date, exoskeletal biofilms and gut microbes will rarely contribute to fixed nitrogen removal at the ecosystem level, but rather exert a significant effect on greenhouse gas emission. Further studies should investigate whether and how much nitrous oxide is emitted by extensively cultivated bivalves. The same is true for oyster reefs and mussel banks that are restored with the aim to improve water quality, but may in fact be significant sources of nitrous oxide. Additionally, animals kept in aquaculture facilities at very high nutrient concentrations should be investigated for their potential to emit nitrous oxide, since extremely high rates of nitrous oxide production are directly associated with the widely cultivated shrimp Litopenaeus vannamei.

\section{Supplementary material related to this article is available online at http://www.biogeosciences.net/10/ 7829/2013/bg-10-7829-2013-supplement.pdf.}


Acknowledgements. I wish to thank Andreas Schramm and Armin Kureck for valuable comments on an earlier version of the manuscript. Ines M. Heisterkamp is acknowledged for fruitful discussions on animal-associated nitrous oxide production. This work was financially supported by the Max Planck Society, the German Research Foundation (grant STI202/6-1), and a Marie Curie Fellowship awarded by the European Commission.

The service charges for this open access publication have been covered by the Max Planck Society.

Edited by: J. Middelburg

\section{References}

Aller, R. C. and Aller, J. Y.: The effect of biogenic irrigation intensity and solute exchange on diagenetic reaction rates in marine sediments, J. Mar. Res., 56, 905-936, 1998.

Altmann, D., Stief, P., Amann, R., and de Beer, D.: Nitrification in freshwater sediments as influenced by insect larvae: Quantification by microsensors and fluorescence in situ hybridization, Microb. Ecol., 48, 145-153, 2004.

Autio, L., Makela, K., Lehtonen, K. K., Kuparinen, J., and Haahti, H.: Effects of algal sedimentation and Monoporeia affinis on nutrient fluxes, pore water profiles and denitrification in sediment microcosms, Boreal Environ. Res., 8, 229-243, 2003.

Banks, J. L., Ross, D. J., Keough, M. J., Macleod, C. K., Keane, J., and Eyre, B. D.: Influence of a burrowing, metal-tolerant polychaete on benthic metabolism, denitrification and nitrogen regeneration in contaminated estuarine sediments, Mar. Pollut. Bull., 68, 30-37, 2013.

Bartoli, M., Nizzoli, D., Welsh, D. T., and Viaroli, P.: Short-term influence of recolonisation by the polychaete worm Nereis succinea on oxygen and nitrogen fluxes and denitrification: a microcosm study, Hydrobiologia, 431, 165-174, 2000.

Bayer, C., Heindl, N. R., Rinke, C., Lucker, S., Ott, J. A., and Bulgheresi, S.: Molecular characterization of the symbionts associated with marine nematodes of the genus Robbea, Environ. Microbiol. Reports, 1, 136-144, 2009.

Bayer, K., Schmitt, S., and Hentschel, U.: Physiology, phylogeny and in situ evidence for bacterial and archaeal nitrifiers in the marine sponge Aplysina aerophoba, Environ. Microbiol., 10, 29422955, 2008.

Bertics, V. J., Sohm, J. A., Magnabosco, C., and Ziebis, W.: Denitrification and nitrogen fixation dynamics in the area surrounding an individual ghost shrimp (Neotrypaea californiensis) burrow system, Appl. Environ. Microbiol., 78, 3864-3872, 2012.

Braeckman, U., Provoost, P., Gribsholt, B., Van Gansbeke, D., Middelburg, J. J., Soetaert, K., Vincx, M., and Vanaverbeke, J.: Role of macrofauna functional traits and density in biogeochemical fluxes and bioturbation, Mar. Ecol. Prog. Ser., 399, 173-186, 2010.

Bruesewitz, D. A., Tank, J. L., Bernot, M. J., Richardson, W. B., and Strauss, E. A.: Seasonal effects of the zebra mussel (Dreissena polymorpha) on sediment denitrification rates in Pool 8 of the Upper Mississippi River, Can. J. Fish. Aquat. Sci., 63, 957-969, 2006.

Bruesewitz, D. A., Tank, J. L., and Bernot, M. J.: Delineating the effects of zebra mussels (Dreissena polymorpha) on $\mathrm{N}$ transfor- mation rates using laboratory mesocosms, J. N. Am. Benthol. Soc., 27, 236-251, 2008.

Bruesewitz, D. A., Tank, J. L., and Hamilton, S. K.: Seasonal effects of zebra mussels on littoral nitrogen transformation rates in Gull Lake, Michigan, USA, Freshwat. Biol., 54, 1427-1443, 2009.

Carlsson, M. S., Glud, R. N., and Petersen, J. K.: Degradation of mussel (Mytilus edulis) fecal pellets released from hanging longlines upon sinking and after settling at the sediment, Can. J. Fish. Aquat. Sci., 67, 1376-1387, 2010.

Carmichael, R. H., Walton, W., and Clark, H.: Bivalve-enhanced nitrogen removal from coastal estuaries, Can. J. Fish. Aquat. Sci., 69, 1131-1149, 2012.

Christensen, B., Vedel, A., and Kristensen, E.: Carbon and nitrogen fluxes in sediment inhabited by suspension-feeding (Nereis diversicolor) and non-suspension-feeding ( $N$. virens) polychaetes, Mar. Ecol. Prog. Ser., 192, 203-217, 2000.

Conroy, J. D., Edwards, W. J., Pontius, R. A., Kane, D. D., Zhang, H. Y., Shea, J. F., Richey, J. N., and Culver, D. A.: Soluble nitrogen and phosphorus excretion of exotic freshwater mussels (Dreissena spp.): potential impacts for nutrient remineralisation in western Lake Erie, Freshwat. Biol., 50, 1146-1162, 2005.

Dame, R. F., Spurrier, J. D., and Zingmark, R. G.: In situ metabolism of an oyster reef, J. Exp. Mar. Biol. Ecol., 164, 147159, 1992.

D'Andrea, A. F. and DeWitt, T. H.: Geochemical ecosystem engineering by the mud shrimp Upogebia pugettensis (Crustacea: Thalassinidae) in Yaquina Bay, Oregon: Density-dependent effects on organic matter remineralization and nutrient cycling, Limnol. Oceanogr., 54, 1911-1932, 2009.

Deines, P., Bodelier, P. L. E., and Eller, G.: Methane-derived carbon flows through methane-oxidizing bacteria to higher trophic levels in aquatic systems, Environ. Microbiol., 9, 1126-1134, 2007.

Dollhopf, S. L., Hyun, J. H., Smith, A. C., Adams, H. J., O’Brien, S., and Kostka, J. E.: Quantification of ammonia-oxidizing bacteria and factors controlling nitrification in salt marsh sediments, Appl. Environ. Microbiol., 71, 240-246, 2005.

Dunn, R. J. K., Welsh, D. T., Jordan, M. A., Teasdale, P. R., and Lemckert, C. J.: Influence of natural amphipod (Victoriopisa australiensis) (Chilton, 1923) population densities on benthic metabolism, nutrient fluxes, denitrification and DNRA in subtropical estuarine sediment, Hydrobiologia 628, 95-109, 2009.

Emmerson, M. C., Solan, M., Emes, C., Paterson, D. M., and Raffaelli, D.: Consistent patterns and the idiosyncratic effects of biodiversity in marine ecosystems, Nature, 411, 73-77, 2001.

Evrard, V., Huettel, M., Cook, P. L. M., Soetaert, K., Heip, C. H. R., and Middelburg, J. J.: Importance of phytodetritus and microphytobenthos for heterotrophs in a shallow subtidal sandy sediment, Mar. Ecol. Prog. Ser., 455, 13-31, 2012.

Fanjul, E., Bazterrica, M. C., Escapa, M., Grela, M. A., and Iribarne, O.: Impact of crab bioturbation on benthic flux and nitrogen dynamics of Southwest Atlantic intertidal marshes and mudflats, Estuar. Coast. Shelf Sci., 92, 629-638, 2011.

Feuchtmayr, H., Moran, R., Hatton, K., Connor, L., Heyes, T., Moss, B., Harvey, I., and Atkinson, D.: Global warming and eutrophication: effects on water chemistry and autotrophic communities in experimental hypertrophic shallow lake mesocosms, J. Appl. Ecol., 46, 713-723, 2009. 
Fiore, C. L., Jarett, J. K., Olson, N. D., and Lesser, M. P.: Nitrogen fixation and nitrogen transformations in marine symbioses, Trends Microbiol., 18, 455-463, 2010.

Fiore, C. L., Labrie, M., and Lesser, M. P.: Pumping activity and nitrogen cycling in the giant barrel sponge, Xestospongia muta, Integr. Comp. Biol., 52, Abstract E245, 2012.

Fonseca Leal, J. J., Esteves, F. D., Farjalla, V. F., and EnrichPrast, A.: Effect of Campsurus notatus on $\mathrm{NH}_{4}^{+}$, DOC fluxes, $\mathrm{O}_{2}$ uptake and bacterioplankton production in experimental microcosms with sediment-water interface of an Amazonian lake impacted by bauxite tailings, Int. Rev. Hydrobiol., 88, 167-178, 2003.

Gardner, W. S., Nalepa, T. F., Slavens, D. R., and Laird, G. A.: Patterns and rates of nitrogen release by benthic Chironomidae and Oligochaeta, Can. J. Fish. Aquat. Sci., 40, 259-266, 1983.

Gardner, W. S., Cavaletto J. F., Johengen T. H., Johnson J. R., Heath R. T., and Cotner J. B.: Effects of the zebra mussel, Dreissena polymorpha, on community nitrogen dynamics in Saginaw Bay, Lake Huron, J. Great Lakes Res., 21, 529-544, 1995.

Gilbert, F., Souchu, P., Bianchi, M., and Bonin, P.: Influence of shellfish farming activities on nitrification, nitrate reduction to ammonium and denitrification at the water-sediment interface of the Thau lagoon, France, Mar. Ecol. Prog. Ser., 151, 143-153, 1997.

Gilbert, F., Aller, R. C., and Hulth, S.: The influence of macrofaunal burrow spacing and diffusive scaling on sedimentary nitrification and denitrification: An experimental simulation and model approach, J. Mar. Res., 61, 101-125, 2003.

Gilbertson, W. W., Solan, M., and Prosser, J. I.: Differential effects of microorganism-invertebrate interactions on benthic nitrogen cycling, FEMS Microbiol. Ecol., 82, 11-22, 2012.

Girguis, P. R., Lee, R. W., Desaulniers, N., Childress, J. J., Pospesel, M., Felbeck, H., and Zal, F.: Fate of nitrate acquired by the tubeworm Riftia pachyptila, Appl. Environ. Microbiol., 66, 2783-2790, 2000.

Goedkoop, W. and Johnson, R. K.: Exploitation of sediment bacterial carbon by juveniles of the amphipod Monoporeia affinis, Freshwat. Biol., 32, 553-563, 1994.

Gruber, N. and Galloway, J. N.: An Earth-system perspective of the global nitrogen cycle, Nature, 451, 293-296, 2008.

Gutierrez, J. L., Jones, C. G., Strayer, D. L., and Iribarne, O. O.: Mollusks as ecosystem engineers: the role of shell production in aquatic habitats, Oikos, 101, 79-90, 2003.

Hamilton, D. J., Ankney, C. D., and Bailey, R. C.: Predation of zebra mussels by diving ducks - an exclosure study, Ecology, 75, 521$531,1994$.

Hansen, K. and Kristensen, E.: The impact of the polychaete Nereis diversicolor and enrichment with macroalgal (Chaetomorpha linum) detritus on benthic metabolism and nutrient dynamics in organic-poor and organic-rich sediment, J. Exp. Mar. Biol. Ecol., 231, 201-223, 1998.

Hatcher, A., Grant, J., and Schofield, B.: Effects of suspended mussel culture (Mytilus spp.) on sedimentation, benthic respiration and sediment nutrient dynamics in a coastal bay, Mar. Ecol. Prog. Ser., 115, 219-235, 1994.

Heisterkamp, I. M., Schramm, A., de Beer, D., and Stief, P.: Nitrous oxide production associated with coastal marine invertebrates, Mar. Ecol. Prog. Ser., 415, 1-9, 2010.
Heisterkamp, I. M., Schramm, A., Larsen, L. H., Svenningsen, N. B., Lavik, G., de Beer, D., and Stief, P.: Shell-biofilm-associated nitrous oxide production in marine molluscs: processes, precursors, and relative importance, Environ. Microbiol., 15, 19431955, 2013.

Heisterkamp, I. M., Kamp, A., Schramm, A. T., de Beer, D., and Stief, P.: Indirect control of the intracellular nitrate pool of intertidal sediment by the polychaete Hediste diversicolor. Mar. Ecol. Progr. Ser., 445, 181-192, 2012.

Henriksen, K., Rasmussen, M.B., and Jensen, A.: Effect of bioturbation on microbial nitrogen transformations in the sediment and fluxes of ammonium and nitrate to the overlying water, Ecol. Bull., 35, 193-205, 1983.

Hentschel, U. and Felbeck, H.: Nitrate respiration in the hydrothermal vent tubeworm Riftia pachyptila, Nature, 366, 338-340, 1993.

Hentschel, U., Berger, E. C., Bright, M., Felbeck, H., and Ott, J. A.: Metabolism of nitrogen and sulfur in ectosymbiotic bacteria of marine nematodes (Nematoda, Stilbonematinae), Mar. Ecol. Prog. Ser., 183, 149-158, 1999

Hentschel, U., Usher, K. M., and Taylor, M. W.: Marine sponges as microbial fermenters, FEMS Microbiol. Ecol., 55, 167-177, 2006.

Hietanen, S., Laine, A. O., and Lukkari, K.: The complex effects of the invasive polychaetes Marenzelleria spp. on benthic nutrient dynamics, J. Exp. Mar. Biol. Ecol., 352, 89-102, 2007.

Higgins, C. B., Stephenson, K., and Brown, B. L.: Nutrient bioassimilation capacity of aquacultured oysters: Quantification of an ecosystem service, J. Environ. Qual., 40, 271-277, 2011.

Higgins, C. B., Tobias, C., Piehler, M. F., Smyth, A. R., Dame, R. F., Stephenson, K., and Brown, B. L.: Effect of aquacultured oyster biodeposition on sediment $\mathrm{N}_{2}$ production in Chesapeake Bay, Mar. Ecol. Prog. Ser., 473, 7-27, 2013.

Higgins, S. N. and Vander Zanden, M. J.: What a difference a species makes: a meta-analysis of dreissenid mussel impacts on freshwater ecosystems, Ecol. Monogr., 80, 179-196, 2010.

Hoffmann, F., Roy, H., Bayer, K., Hentschel, U., Pfannkuchen, M., Bruemmer, F., and de Beer, D.: Oxygen dynamics and transport in the Mediterranean sponge Aplysina aerophoba, Mar. Biol., 153, 1257-1264, 2008.

Hoffmann, F., Radax, R., Woebken, D., Holtappels, M., Lavik, G., Rapp, H. T., Schläppy, M. L., Schleper, C., and Kuypers, M. M. M.: Complex nitrogen cycling in the sponge Geodia barretti, Environ. Microbiol., 11, 2228-2243, 2009.

Howarth, R., Chan, F., Conley, D. J., Garnier, J., Doney, S. C., Marino, R., and Billen, G.: Coupled biogeochemical cycles: eutrophication and hypoxia in temperate estuaries and coastal marine ecosystems, Front. Ecol. Environ., 9, 18-26, 2011.

Howe, R. L., Rees, A. P., and Widdicombe, S.: The impact of two species of bioturbating shrimp (Callianassa subterranea and Upogebia deltaura) on sediment denitrification, J. Mar. Biol. Assoc. U. K., 84, 629-632, 2004.

Jenkins, M. C. and Kemp, W. M.: The coupling of nitrification and denitrification in two estuarine sediments, Limnol. Oceanogr., 29, 609-619, 1984.

Jimenez, E. and Ribes, M.: Sponges as a source of dissolved inorganic nitrogen: Nitrification mediated by temperate sponges, Limnol. Oceanogr., 52, 948-958, 2007. 
Johnson, R. K., Boström, B., and Van de Bund, W. J.: Interactions between Chironomus plumosus L. and the microbial community in surficial sediments of a shallow eutrophic lake, Limnol. Oceanogr., 34, 992-1003, 1989.

Jones, C. G., Lawton, J. H., and Shachak, M.: Organisms as ecosystem engineers, Oikos, 69, 373-386, 1994.

Jordan, M. A., Welsh, D. T., Dunn, R. J. K., and Teasdale, P. R.: Influence of Trypaea australiensis population density on benthic metabolism and nitrogen dynamics in sandy estuarine sediment: A mesocosm simulation, J. Sea Res., 61, 144-152, 2009.

Kamp, A. and Witte, U.: Processing of ${ }^{13} \mathrm{C}$-labelled phytoplankton in a fine-grained sandy-shelf sediment (North Sea): relative importance of different macrofauna species, Mar. Ecol. Progr. Ser., 297, 61-70, 2005.

Kamp, A., de Beer, D., Nitsch, J. L., Lavik, G., and Stief, P.: Diatoms respire nitrate to survive dark and anoxic conditions. Proc. Natl. Acad. Sci., 108, 5649-5654, 2011.

Kana, T. M., Darkangelo, C., Hunt, M. D., Oldham, J. B., Bennett, G. E., and Cornwell, J. C.: Membrane inlet mass-spectrometer for rapid high-precision determination of $\mathrm{N}_{2}, \mathrm{O}_{2}$, and $\mathrm{Ar}$ in environmental water samples, Anal. Chem., 66, 4166-4170, 1994.

Karlson, K., Hulth, S., Ringdahl, K., and Rosenberg, R.: Experimental recolonisation of Baltic Sea reduced sediments: survival of benthic macrofauna and effects on nutrient cycling, Mar. Ecol. Prog. Ser., 294, 35-49, 2005.

Karlson, K., Hulth, S., and Rosenberg, R.: Density of Monoporeia affinis and biogeochemistry in Baltic Sea sediments, J. Exp. Mar. Biol. Ecol., 344, 123-135, 2007.

Kellogg, M. L., Cornwell, J. C., Owens, M S., and Paynter, K. T.: Denitrification and nutrient assimilation on a restored oyster reef, Mar. Ecol. Prog. Ser., 480, 1-19, 2013.

Kemp, P. F.: Potential impact on bacteria of grazing by a macrofaunal deposit-feeder, and the fate of bacterial production, Mar. Ecol. Prog. Ser., 36, 151-161, 1987.

Kikuchi, Y., Bomar, L., and Graf, J.: Stratified bacterial community in the bladder of the medicinal leech, Hirudo verbena, Environ. Microbiol., 11, 2758-2770, 2009.

Kristensen, E. and Kostka, J. E.: Macrofaunal burrows and irrigation in marine sediment: Microbiological and biogeochemical interactions. In: Interactions between macro- and microorganisms in marine sediments, Eds.: Kristensen, E., Haese,R. R., and Kostka, J. E., pp. 125-157, AGU, Washington DC, 2005.

Kristensen, E., Jensen, M. H., and Aller, R. C.: Direct measurement of dissolved inorganic nitrogen exchange and denitrification in individual polychaete Nereis virens burrows, J. Mar. Res., 49, 355-378, 1991.

Kristensen, E., Hansen, T., Delefosse, M., Banta, G. T., and Quintana, C. O.: Contrasting effects of the polychaetes Marenzelleria viridis and Nereis diversicolor on benthic metabolism and solute transport in sandy coastal sediment, Mar. Ecol. Prog. Ser., 425, 125-139, 2011.

Kristensen, E., Penha-Lopes, G., Delefosse, M., Valdemarsen, T., Quintana, C. O., and Banta, G. T.: What is bioturbation? The need for a precise definition for fauna in aquatic sciences, Mar. Ecol. Prog. Ser., 446, 285-302, 2012.

Laverock, B., Gilbert, J. A., Tait, K., Osborn, A. M., and Widdicombe, S.: Bioturbation: impact on the marine nitrogen cycle, Biochem. Soc. Transact., 39, 315-320, 2011.
Lavrentyev, P. J., Gardner, W. S., and Yang, L.: Effects of the zebra mussel on nitrogen dynamics and the microbial community at the sediment-water interface, Aquat. Microb. Ecol., 21, 187-194, 2000.

Lechene, C. P., Luyten, Y., McMahon, G., and Distel, D. L.: Quantitative imaging of nitrogen fixation by individual bacteria within animal cells, Science, 317, 1563-1566, 2007.

Lenihan, H.S.: Physical-biological coupling on oyster reefs: How habitat structure influences individual performance, Ecol. Monogr., 69, 251-275, 1999.

Levin, L. A. and Michener, R. H.: Isotopic evidence for chemosynthesis-based nutrition of macrobenthos: The lightness of being at Pacific methane seeps, Limnol. Oceanogr., 47, 13361345, 2002.

Lewandowski, J., Laskov, C., and Hupfer, M.: The relationship between Chironomus plumosus burrows and the spatial distribution of pore-water phosphate, iron and ammonium in lake sediments, Freshwat. Biol., 52, 331-343, 2007.

Markert, A., Wehrmann, A., and Kroncke, I.: Recently established Crassostrea-reefs versus native Mytilus-beds: differences in ecosystem engineering affects the macrofaunal communities (Wadden Sea of Lower Saxony, southern German Bight), Biol. Invas., 12, 15-32, 2010.

Martinez-Garcia, M., Stief, P., Diaz-Valdes, M., Wanner, G., Ramos-Espla, A., Dubilier, N., and Anton, J.: Ammoniaoxidizing Crenarchaeota and nitrification inside the tissue of a colonial ascidian, Environ. Microbiol., 10, 2991-3001, 2008.

Mayer, M. S., Schaffner, L., and Kemp, W. M.: Nitrification potentials of benthic macrofaunal tubes and burrow walls: effects of sediment $\mathrm{NH}_{4}^{+}$and animal irrigation behavior, Mar. Ecol. Prog. Ser., 121, 157-169, 1995.

McFall-Ngai, M., Hadfield, M. G., Bosch, T. C. G., Carey, H. V., Domazet-Loso, T., Douglas, A. E., Dubilier, N., Eberl, G., Fukami, T., Gilbert, S. F., Hentschel, U., King, N., Kjelleberg, S., Knoll, A. H., Kremer, N., Mazmanian, S. K., Metcalf, J. L., Nealson, K., Pierce, N. E., Rawls, J. F., Reid, A., Ruby, E. G., Rumpho, M., Sanders, J. G., Tautz, D., and Wernegreen, J. J.: Animals in a bacterial world, a new imperative for the life sciences, Proc. Natl. Acad. Sci., 110, 3229-3236, 2013.

Meysman, F. J. R., Middelburg, J. J., and Heip, C. H. R.: Bioturbation: a fresh look at Darwin's last idea, Trends Ecol. Evol., 21, 688-695, 2006.

Michaud, E., Desrosiers, G., Mermillod-Blondin, F., Sundby, B., and Stora, G.: The functional group approach to bioturbation: II. The effects of the Macoma balthica community on fluxes of nutrients and dissolved organic carbon across the sediment-water interface, J. Exp. Mar. Biol. Ecol., 337, 178-189, 2006.

Na, T., Gribsholt, B., Galaktionov, O. S., Lee, T., and Meysman, F. J. R.: Influence of advective bio-irrigation on carbon and nitrogen cycling in sandy sediments, J. Mar. Res., 66, 691-722, 2008.

Newell, R. I. E., Cornwell, J. C., and Owens, M. S.: Influence of simulated bivalve biodeposition and microphytobenthos on sediment nitrogen dynamics: A laboratory study, Limnol. Oceanogr., 47, 1367-1379, 2002.

Newell, R. I. E., Fisher, T. R., Holyoke, R. R., and Cornwell, J. C.: Influence of eastern oysters on nitrogen and phosphorus regeneration in Chesapeake Bay, USA. Comparative roles of suspensionfeeders, Ecosystems, 47, 93-120, 2005. 
Nielsen L. P.: Denitrification in sediment determined from nitrogen isotope pairing, FEMS Microbiol. Ecol., 86, 357-362, 1992.

Nielsen, O. I., Gribsholt, B., Kristensen, E., and Revsbech, N. P.: Microscale distribution of oxygen and nitrate in sediment inhabited by Nereis diversicolor: spatial patterns and estimated reaction rates, Aquat. Microb. Ecol., 34, 23-32, 2004.

Nixon, S. W.: Coastal marine eutrophication: A definition, social causes, and future concerns, Ophelia 41, 199-219, 1995.

Nizzoli, D., Welsh, D.T., Bartoli, M., and Viaroli, P.: Impacts of mussel (Mytilus galloprovincialis) farming on oxygen consumption and nutrient recycling in a eutrophic coastal lagoon, Hydrobiologia, 550, 183-198, 2005.

Nizzoli, D., Bartoli, M., and Viaroli, P.: Nitrogen and phosphorous budgets during a farming cycle of the Manila clam Ruditapes philippinarum: An in situ experiment. Aquaculture, 261, 98-108, 2006a.

Nizzoli, D., Welsh, D. T., Fano, E. A., and Viaroli, P.: Impact of clam and mussel farming on benthic metabolism and nitrogen cycling, with emphasis on nitrate reduction pathways, Mar. Ecol. Prog. Ser., 315, 151-165, 2006b.

Nizzoli, D., Bartoli, M., Cooper, M., Welsh, D. T., Underwood, G. J. C., and Viaroli, P.: Implications for oxygen, nutrient fluxes and denitrification rates during the early stage of sediment colonisation by the polychaete Nereis spp. in four estuaries, Estuar. Coast. Shelf Sci., 75, 125-134, 2007.

O'Neil, J. M. and Capone, D. G.: Nitrogen cycling in coral reef environments. In: Nitrogen in the marine environment, Eds.: Capone, D. G., Bronk, D. A., Mulholland, M. R., and Carpenter, E. J., pp. 949-989, Academic Press, 2008.

Papaspyrou, S., Gregersen, T., Cox, R. P., Thessalou-Legaki, M., and Kristensen, E.: Sediment properties and bacterial community in burrows of the ghost shrimp Pestarella tyrrhena (Decapoda: Thalassinidea), Aquat. Microb. Ecol., 38, 181-190, 2005.

Pascal, P. Y., Dupuy, C., Mallet, C., Richard, P., and Niquil, N.: Bacterivory by benthic organisms in sediment: Quantification using ${ }^{15} \mathrm{~N}$-enriched bacteria, J. Exp. Mar. Biol. Ecol., 355, 18-26, 2008.

Pejchar, L. and Mooney, H. A.: Invasive species, ecosystem services and human well-being, Trends Ecol. Evol., 24, 497-504, 2009.

Pelegri, S. P. and Blackburn, T. H.: Bioturbation effects of the amphipod Corophium volutator on microbial nitrogen transformations in marine sediments, Mar. Biol., 121, 253-258, 1994.

Pelegri, S. P. and Blackburn, T. H.: Effect of bioturbation by Nereis sp., Mya arenaria and Cerastoderma sp. on nitrification and denitrification in estuarine sediments, Ophelia, 42, 289-299, 1995a.

Pelegri, S. P. and Blackburn, T. H.: Effects of Tubifex tubifex (Oligochaeta: Tubificidae) on N-mineralization in freshwater sediments, measured with ${ }^{15} \mathrm{~N}$ isotopes, Aquat. Microb. Ecol., 9, 289-294, 1995b.

Pelegri, S. P. and Blackburn, T. H.: Nitrogen cycling in lake sediments bioturbated by Chironomus plumosus larvae, under different degrees of oxygenation, Hydrobiologia, 325, 231-238, 1996.

Pelegri, S. P., Nielsen, L. P., and Blackburn, T. H.: Denitrification in estuarine sediment stimulated by the irrigation activity of the amphipod Corophium volutator, Mar. Ecol. Prog. Ser., 105, 285290, 1994.

Piehler, M. F. and Smyth, A. R.: Habitat-specific distinctions in estuarine denitrification affect both ecosystem function and services, Ecosphere, 2, 1-16, 2011.
Plante, C. J. and Jumars, P.: The microbial environment of marine deposit-feeder guts characterized via microelectrodes, Microb. Ecol., 23, 257-277, 1992.

Plante, C. J. and Mayer, L. M.: Distribution and efficiency of bacteriolysis in the gut of Arenicola marina and three additional deposit feeders, Mar. Ecol. Prog. Ser., 109, 183-194, 1994.

Plante, C. J. and Wilde, S. B.: Bacterial recolonization of deposit-feeder egesta: In situ regrowth or immigration?, Limnol. Oceanogr., 46, 1171-1181, 2001.

Plutchak, R., Major, K., Cebrian, J., Foster, C. D., Miller, M. E. C., Anton, A., Sheehan, K. L., Heck, K. L., and Powers, S. P.: Impacts of oyster reef restoration on primary productivity and nutrient dynamics in tidal creeks of the North Central Gulf of Mexico, Estuar. Coasts, 33, 1355-1364, 2010.

Poulsen, M., Kofoed, M. V. W., Larsen, L. H., Schramm, A., and Stief, P.: Chironomus plumosus larvae increase fluxes of denitrification products and diversity of nitratereducing bacteria in freshwater sediment, Syst. Appl. Microbiol., doi:10.1016/j.syapm.2013.07.006, 2013.

Prins, T. C. and Smaal, A. C.: The role of the blue mussel Mytilus edulis in the cycling of nutrients in the Oosterschelde Estuary (the Netherlands), Hydrobiologia 283, 413-429, 1994.

Rabalais, N. N.: Nitrogen in aquatic ecosystems, Ambio, 31, 102$112,2002$.

Radax, R., Hoffmann, F., Rapp, H. T., Leininger, S., and Schleper, C.: Ammonia-oxidizing archaea as main drivers of nitrification in cold-water sponges, Environ. Microbiol., 14, 909-923, 2012a.

Radax, R., Rattei, T., Lanzen, A., Bayer, C., Rapp, H. T., Urich, T., and Schleper, C.: Metatranscriptomics of the marine sponge Geodia barretti: tackling phylogeny and function of its microbial community, Environ. Microbiol., 14, 1308-1324, 2012b.

Rose, J. M., Ferreira, J. G., Stephenson, K., Bricker, S. B., Tedesco, M., and Wikfors, G. H.: Comment on Stadmark and Conley (2011) "Mussel farming as a nutrient reduction measure in the Baltic Sea: Consideration of nutrient biogeochemical cycles", Mar. Pollut. Bull., 64, 449-451, 2012.

Roskosch, A., Morad, M. R., Khalili, A., and Lewandowski, J.: Bioirrigation by Chironomus plumosus: advective flow investigated by particle image velocimetry, J. N. Am. Benthol. Soc., 29, 789-802, 2010.

Satoh, H., Nakamura, Y., and Okabe, S.: Influences of infaunal burrows on the community structure and activity of ammoniaoxidizing bacteria in intertidal sediments, Appl. Environ. Microbiol., 73, 1341-1348, 2007.

Schläppy, M. L., Hoffmann, F., Roy, H., Wijffels, R. H., Mendola, D., Sidri, M., and de Beer, D.: Oxygen dynamics and flow patterns of Dysidea avara (Porifera: Demospongiae), J. Mar. Biol. Assoc. U. K., 87, 1677-1682, 2007.

Schläppy, M. L., Schottner, S. I., Lavik, G., Kuypers, M. M. M., de Beer, D., and Hoffmann, F.: Evidence of nitrification and denitrification in high and low microbial abundance sponges, Mar Biol., 157, 593-602, 2010a.

Schläppy, M. L., Weber, M., Mendola, D., Hoffmann, F., and de Beer, D.: Heterogeneous oxygenation resulting from active and passive flow in two Mediterranean sponges, Dysidea avara and Chondrosia reniformis, Limnol. Oceanogr., 55, 1289-1300, $2010 b$. 
Seitzinger, S. P. and Kroeze, C.: Global distribution of nitrous oxide production and $\mathrm{N}$ inputs in freshwater and coastal marine ecosystems, Glob. Biogeochem. Cycl., 12, 93-113, 1998.

Sørensen, J.: Denitrification rates in a marine sediment as measured by the acetylene inhibition technique, Appl. Environ. Microbiol., 36, 139-143, 1978.

Souchu, P., Vaquer, A., Collos, Y., Landrein, S., Deslous-Paoli, J.M., and Bibent, B.: Influence of shellfish farming activities on the biogeochemical composition of the water column in Thau lagoon, Mar. Ecol. Prog. Ser., 218, 141-152, 2001.

Stadmark, J. and Conley, D.J.: Mussel farming as a nutrient reduction measure in the Baltic Sea: consideration of nutrient biogeochemical cycles, Mar. Pollut. Bull., 62, 1385-1388, 2011.

Stenton-Dozey, J., Probyn, T., and Busby, A.: Impact of mussel (Mytilus galloprovincialis) raft-culture on benthic macrofauna, in situ oxygen uptake, and nutrient fluxes in Saldanha Bay, South Africa, Can. J. Fish. Aquat. Sci., 58, 1021-1031, 2001.

Stief, P.: Enhanced exoenzyme activities in sediments in the presence of deposit-feeding Chironomus riparius larvae, Freshwat. Biol., 52, 1807-1819, 2007.

Stief, P. and de Beer, D.: Probing the microenvironment of freshwater sediment macrofauna: Implications of deposit-feeding and bioirrigation for nitrogen cycling, Limnol. Oceanogr., 51, 2538$2548,2006$.

Stief, P. and Eller, G.: The gut microenvironment of sedimentdwelling Chironomus plumosus larvae as characterised with $\mathrm{O}_{2}$, pH and redox microsensors, J. Comp. Physiol. B, 176, 673-683, 2006.

Stief, P. and Hölker, F.: Trait-mediated indirect effects of predatory fish on microbial mineralization in aquatic sediments, Ecology, 87, 3152-3159, 2006.

Stief, P. and Schramm, A.: Regulation of nitrous oxide emission associated with benthic invertebrates, Freshwat. Biol., 55, 1647$1657,2010$.

Stief, P., Altmann, D., de Beer, D., Bieg, R., and Kureck, A.: Microbial activities in the burrow environment of the potamal mayfly Ephoron virgo, Freshwat. Biol., 49, 1152-1163, 2004.

Stief, P., Poulsen, M., Nielsen, L. P., Brix, H., and Schramm, A.: Nitrous oxide emission by aquatic macrofauna, Proc. Natl. Acad. Sci., 106, 4296-4300, 2009.

Stief, P., Polerecky, L., Poulsen, M., and Schramm, A.: Control of nitrous oxide emission from Chironomus plumosus larvae by nitrate and temperature, Limnol. Oceanogr., 55, 872-884, 2010.

Stief, P., Kamp, A., and de Beer, D.: Role of diatoms in the spatial-temporal distribution of intracellular nitrate in intertidal sediment, PLoS ONE, 8, e73257, doi:10.1371/journal.pone.0073257, 2013.

Strayer, D. L.: Twenty years of zebra mussels: lessons from the mollusk that made headlines, Front. Ecol. Environ. 7, 135-141, 2009.

Svenningsen, N. B., Heisterkamp, I. M., Sigby-Clausen, M., Larsen, L. H., Nielsen, L. P., Stief, P., and Schramm, A.: Shell biofilm nitrification and gut denitrification contribute to emission of nitrous oxide by the invasive freshwater mussel Dreissena polymorpha (zebra mussel), Appl. Environ. Microbiol., 78, 4505-4509, 2012.

Svensson, J. M.: Influence of Chironomus plumosus larvae on ammonium flux and denitrification (measured by the acetylene blockage- and the isotope pairing-technique) in eutrophic lake sediment, Hydrobiologia, 346, 157-168, 1997.
Svensson, J. M.: Emission of $\mathrm{N}_{2} \mathrm{O}$, nitrification and denitrification in a eutrophic lake sediment bioturbated by Chironomus plumosus, Aquat. Microb. Ecol., 14, 289-299, 1998.

Svensson, J. M. and Leonardson, L.: Effects of bioturbation by tubedwelling chironomid larvae on oxygen uptake and denitrification in eutrophic lake sediments, Freshwat. Biol., 35, 289-300, 1996.

Svensson, J. M., Enrich-Prast, A., and Leonardson, L.: Nitrification and denitrification in a eutrophic lake sediment bioturbated by oligochaetes, Aquat. Microb. Ecol., 23, 177-186, 2001.

Tang, K. W., Glud, R. N., Glud, A., Rysgaard, S., and Nielsen, T. G.: Copepod guts as biogeochemical hotspots in the sea: Evidence from microelectrode profiling of Calanus spp., Limnol. Oceanogr., 56, 666-672, 2011.

Thamdrup, B.: New pathways and processes in the global nitrogen cycle, Annu. Rev. Ecol. Evol. Syst., 43, 407-428, 2012.

Thamdrup, B. and Dalsgaard, T.: Nitrogen cycling in sediments. $M i$ crobial Ecology of the Oceans., edited by: Kirchman, D. L., John Wiley and Sons, New York, 527-568, 2008.

van de Bund, W. J., Goedkoop, W., and Johnson, R. K.: Effects of deposit-feeder activity on bacterial production and abundance in profundal lake sediment, J. N. Am. Benthol. Soc., 13, 532-539, 1994.

van Oevelen, D., Moodley, L., Soetaert, K., and Middelburg, J. J.: The trophic significance of bacterial carbon in a marine intertidal sediment: Results of an in situ stable isotope labeling study, Limnol. Oceanogr., 51, 2349-2359, 2006a.

van Oevelen, D., Middelburg, J. J., Soetaert, K., and Moodley, L.: The fate of bacterial carbon in an intertidal sediment: Modeling an in situ isotope tracer experiment, Limnol. Oceanogr., 51, 1302-1314, 2006b.

Veuger, B., Eyre, B. D., Maher, D., and Middelburg, J. J.: Nitrogen incorporation and retention by bacteria, algae, and fauna in a subtropical intertidal sediment: An in situ ${ }^{15} \mathrm{~N}$-labeling study, Limnol. Oceanogr., 52, 1930-1942, 2007.

Wahl, M., Goecke, F., Labes, A., Dobretsov, S., and Weinberger, F.: The second skin: ecological role of epibiotic biofilms on marine organisms, Front. Microbiol., 3, Art. 292, 2012.

Webb, A. P. and Eyre, B. D.: Effect of natural populations of burrowing thalassinidean shrimp on sediment irrigation, benthic metabolism, nutrient fluxes and denitrification, Mar. Ecol. Prog. Ser., 268, 205-220, 2004.

Webster, N. S. and Taylor, M. W.: Marine sponges and their microbial symbionts: love and other relationships, Environ. Microbiol., 14, 335-346, 2012.

Weisz, J. B., Hentschel, U., Lindquist, N., and Martens, C. S.: Linking abundance and diversity of sponge-associated microbial communities to metabolic differences in host sponges, Mar. Biol., 152, 475-483, 2007.

Welsh, D. T. and Castadelli, G.: Bacterial nitrification activity directly associated with isolated benthic marine animals, Mar. Biol., 144, 1029-1037, 2004.

Welsh, D. T., Dunn, R. J. K., and Meziane, T.: Oxygen and nutrient dynamics of the upside down jellyfish (Cassiopea sp.) and its influence on benthic nutrient exchanges and primary production, Hydrobiologia, 635, 351-362, 2009. 